\title{
Molecular Biology and Infection of Hepatitis E Virus
}

\author{
Yuchen $\mathrm{Nan}^{1,2 *}$ and Yan-Jin Zhang ${ }^{2 *}$ \\ ${ }^{1}$ Department of Preventive Veterinary Medicine, College of Veterinary Medicine, Northwest A\&F University, Yangling, China, \\ ${ }^{2}$ Molecular Virology Laboratory, VA-MD College of Veterinary Medicine and Maryland Pathogen Research Institute, \\ University of Maryland, College Park, College Park, MD, USA
}

\section{OPEN ACCESS}

Edited by:

Koichi Watashi,

National Institute of Infectious

Diseases, Japan

Reviewed by:

Marta Canuti,

Memorial University of Newfoundland,

Canada

Qiuwei Pan,

Erasmus University Medical Center

Netherlands

Kavita Satish Lole,

National Institute of Virology, India

${ }^{*}$ Correspondence:

Yuchen Nan

nanyuchen2015@nwsuaf.edu.cn

Yan-Jin Zhang

zhangyj@umd.edu

Specialty section:

This article was submitted to

Virology,

a section of the journal

Frontiers in Microbiology

Received: 22 June 2016 Accepted: 26 August 2016 Published: 07 September 2016

Citation:

Nan Y and Zhang Y-J (2016) Molecular Biology and Infection of Hepatitis E Virus.

Front. Microbiol. 7:1419. doi: 10.3389/fmicb.2016.01419
Hepatitis E virus (HEV) is a viral pathogen transmitted primarily via fecal-oral route. In humans, HEV mainly causes acute hepatitis and is responsible for large outbreaks of hepatitis across the world. The case fatality rate of HEV-induced hepatitis ranges from 0.5 to $3 \%$ in young adults and up to $30 \%$ in infected pregnant women. HEV strains infecting humans are classified into four genotypes. HEV strains from genotypes 3 and 4 are zoonotic, whereas those from genotypes 1 and 2 have no known animal reservoirs. Recently, notable progress has been accomplished for better understanding of HEV biology and infection, such as chronic HEV infection, in vitro cell culture system, quasienveloped HEV virions, functions of the HEV proteins, mechanism of HEV antagonizing host innate immunity, HEV pathogenesis and vaccine development. However, further investigation on the cross-species HEV infection, host tropism, vaccine efficacy, and HEV-specific antiviral strategy is still needed. This review mainly focuses on molecular biology and infection of HEV and offers perspective new insight of this enigmatic virus.

\section{Keywords: hepatitis E virus, HEV, HEV biology, viral proteins of HEV, HEV infection, HEV vaccine}

\section{INTRODUCTION}

Hepatitis E virus (HEV) is a positive-sense, single-stranded RNA virus, and is classified in the genus Orthohepevirus, the family Hepeviridae (Smith et al., 2014). The HEV-caused hepatitis E is generally a self-limiting disease with a case fatality rate from 0.5 to $3 \%$ in young adults but up to $30 \%$ in infected pregnant women in their third trimester of gestation (Jameel, 1999; Nan, 2014). World Health Organization (WHO) estimates that there are 20 million infections with over 3 million symptomatic cases and 56,600 deaths annually across the world (WHO, 2015). HEV is primarily transmitted via fecal-oral route. HEV infection was previously thought to be a public health problem only for the developing countries. Indeed, hepatitis $\mathrm{E}$ is highly endemic in East and South Asia, as well as Africa according to the WHO (WHO, 2015). HEV strains infecting humans are classified into four genotypes. HEV strains from genotypes 3 and 4 are zoonotic, whereas, those from genotypes 1 and 2 have no known animal origin. Discovery of HEV from swine and other species suggests that genotypes 3 and 4 HEV has a wide host range (Christensen et al., 2008; Dalton et al., 2008; Meng, 2013; Pavio et al., 2015). Currently, hepatitis E is frequently recognized in industrialized countries, where it was not thought to be endemic (Kwo et al., 1997; Erker et al., 1999; Schlauder et al., 1999; Worm et al., 2000; Kabrane-Lazizi et al., 2001; Mizuo et al., 2002; Sadler et al., 2006). Moreover, along with isolation of HEV from the pig, chicken, mongoose, rabbit, rat, ferret, bat, fish, and deer (Meng et al., 1997; Haqshenas et al., 2001; Li et al., 2005c; Cossaboom et al., 2012; Smith et al., 2014), cross-species infection of HEV from animal reservoirs to humans is thought to be the major cause of sporadic cases of hepatitis $\mathrm{E}$ in the industrialized 
countries (Pavio et al., 2015). Although previously thought to only cause acute infections, HEV is found in chronic infections reported both in immune compromised and immunocompetent individuals (Hoofnagle et al., 2012; Grewal et al., 2014). In addition, extrahepatic manifestations, such as neurological disorders and kidney injury in HEV infected patients have been documented (Kamar et al., 2011, 2012b; van Eijk et al., 2014; Dalton et al., 2016; Geng et al., 2016). Taken together, current knowledge for HEV implies a significant underestimation of HEV infection as a public health concern. In the following sections, recent progress in HEV biology, functions of viral proteins, cell culture system, epidemiology, viral pathogenesis, treatment, and vaccine development are reviewed and perspective new insights are discussed.

\section{HEV BIOLOGY}

Hepatitis E was initially designated as enterically transmitted non-A, non-B hepatitis (ET-NANBH) due to similar clinical presentations to hepatitis $\mathrm{A}$ and $\mathrm{B}$ in patients, but the prospective causative agent was initially unknown (Balayan et al., 1983). Early research implied that an RNA virus was the potential pathogen for the ET-NANBH. By analysis of a cDNA library from infectious bile sample, a portion of a highly conserved RNAdependent RNA-polymerase (RdRp) motif, commonly found in RNA viruses, was identified (Reyes et al., 1990). This new virus was designated as $\mathrm{HEV}$, which was responsible for the outbreak of ET-NANBH.

The complete sequence of HEV genome was published 1 year later (Tam et al., 1991). Sequence analysis indicated that HEV contains a $7.2 \mathrm{~kb}$ single-stranded positive-sense RNA genome, which is capped and poly-adenylated (Ahmad et al., 2011). There are three partially overlapped open reading frames (ORFs) in an order of sequences encoding non-structural proteins (NSPs) followed by structural protein (Tam et al., 1991; Tsarev et al., 1992; Figure 1). HEV ORF1 encodes a non-structural polyprotein that consists of replicase proteins needed for HEV replication. ORF2 encodes the capsid protein, which is the major structural protein of the HEV virions, which are non-enveloped particles of 32-34 nm in diameter (Mori and Matsuura, 2011). ORF3 encodes a small multifunctional protein with a molecular mass of $13 \mathrm{kDa}$ (VP13). There are also short untranslated regions (UTRs) in both the $5^{\prime}$ and $3^{\prime}$-end of the genome. Recently, an ORF4 was identified from genotype $1 \mathrm{HEV}$ solely (Nair et al., 2016; Figure 1). Expression of ORF4 is cap-independent and driven by a putative IRES-like element between 2701 and $2787 \mathrm{nt}$ of the HEV genome (Nair et al., 2016).

The ORF1 of HEV can be translated directly from the genomic RNA, whereas ORF2 and ORF3 are translated soly from the sub-genomic RNA in alternative frames (Graff et al., 2006). In an earlier report, three RNA species were detected in liver tissue of experimentally infected macaques, with sizes of 7.2, 3.7, and $2 \mathrm{~kb}$ (Tam et al., 1991). The 3.7 and $2 \mathrm{~kb}$ RNA species were thought to be sub-genomic RNAs for translation of ORF2 and ORF3, respectively. However, a later study in Huh7 cells only identified one capped $2.2 \mathrm{~kb}$ sub-genomic RNA, which is a bicistronic mRNA for translation of both ORF2 and ORF3 (Graff et al., 2006). Transcription of this sub-genomic RNA initiates at nucleotide position 5122 in the Sar55 strain, which is located downstream of the first two methionine codons of the initially presumed ORF3. The same conclusion was drawn from another in vitro study of genotype $3 \mathrm{HEV}$ infection in PLC/PRF/5 hepatoma cells (Ichiyama et al., 2009). The HEV genome contains two cis-reactive elements (CREs) that are essential for the viral replication (Cao et al., 2010; Parvez, 2015b). The first CRE overlaps the $3^{\prime}$ end of ORF2 and the $3^{\prime}$ UTR and is essential for HEV replication. The second CRE locates in the intergenic region of the HEV genome and forms a stem-loop structure that may be the promoter for synthesis of the 2.2-kb subgenomic RNA (Cao et al., 2010).

\section{GENOTYPES OF HEV STRAINS}

Hepatitis E virus was initially classified as a member of the Caliciviridae family. However, sequence analysis of HEV ORF1 indicated no similarity to Caliciviruses, or other picorna-like viruses. On the other hand, there is limited but significant similarity to the alphavirus-like superfamily of RNA viruses, specifically, the rubella virus (Berke and Matson, 2000). Consequently, HEV was classified into the family Hepeviridae (Berke and Matson, 2000; Emerson and Purcell, 2003).

Although HEV strains are highly diverse and heterogenic, only one serotype of HEV exists. Classification of HEV strains is under transition due to the different criteria used (Smith et al., 2013, 2014). Recently, a new proposal for the classification of the family Hepeviridae was published (Smith et al., 2014). In this proposal, the family Hepeviridae contains two genera: Orthohepevirus (all mammalian and avian $\mathrm{HEV}$ isolates) and Piscihepevirus (trout HEV; Table 1). Within the genus Orthohepevirus, four different species (A, B, C, D) are designated to include isolates from different hosts (Smith et al., 2014). All four previously recognized HEV genotypes (1-4) that infect humans belong to the Orthohepevirus A virus (Smith et al., 2014).

The previously recognized HEV genotypes 1-4 classification system was based on complete genomic sequences ( $\mathrm{Lu}$ et al., 2006). HEV genotype 1 is the most conserved among the four genotypes. There is only one full-length genotype 2 sequence available (Smith et al., 2016). Both HEV genotypes 1 and 2 are restricted to humans with no known animal reservoirs, whereas genotypes 3 and 4 are zoonotic with an expanded host range (Table 1; Meng, 2010; Ahmad et al., 2011). Therefore, genotypes 3 and $4 \mathrm{HEV}$ strains are highly diverse (Lu et al., 2006; Smith et al., 2014). Since the constant discovery of new HEV or HEV-related isolates from rabbit, rat, ferret, bat, moose, farmed mink, camel, and wild boar (Lorenzo et al., 2007; Zhao et al., 2009; Johne et al., 2010; Geng et al., 2011; Takahashi et al., 2011; Drexler et al., 2012; Raj et al., 2012; Krog et al., 2013; Lin et al., 2014; Woo et al., 2014), four genotypes are no longer satisfying classification of expanding HEV isolates. In the new classification system, some HEV strains from wild boars in Japan with unique viral nucleotide sequences are designated as genotypes 5 and 6, while HEV from camel is classified as genotype 7 of Orthohepevirus A (Smith et al., 2014). 


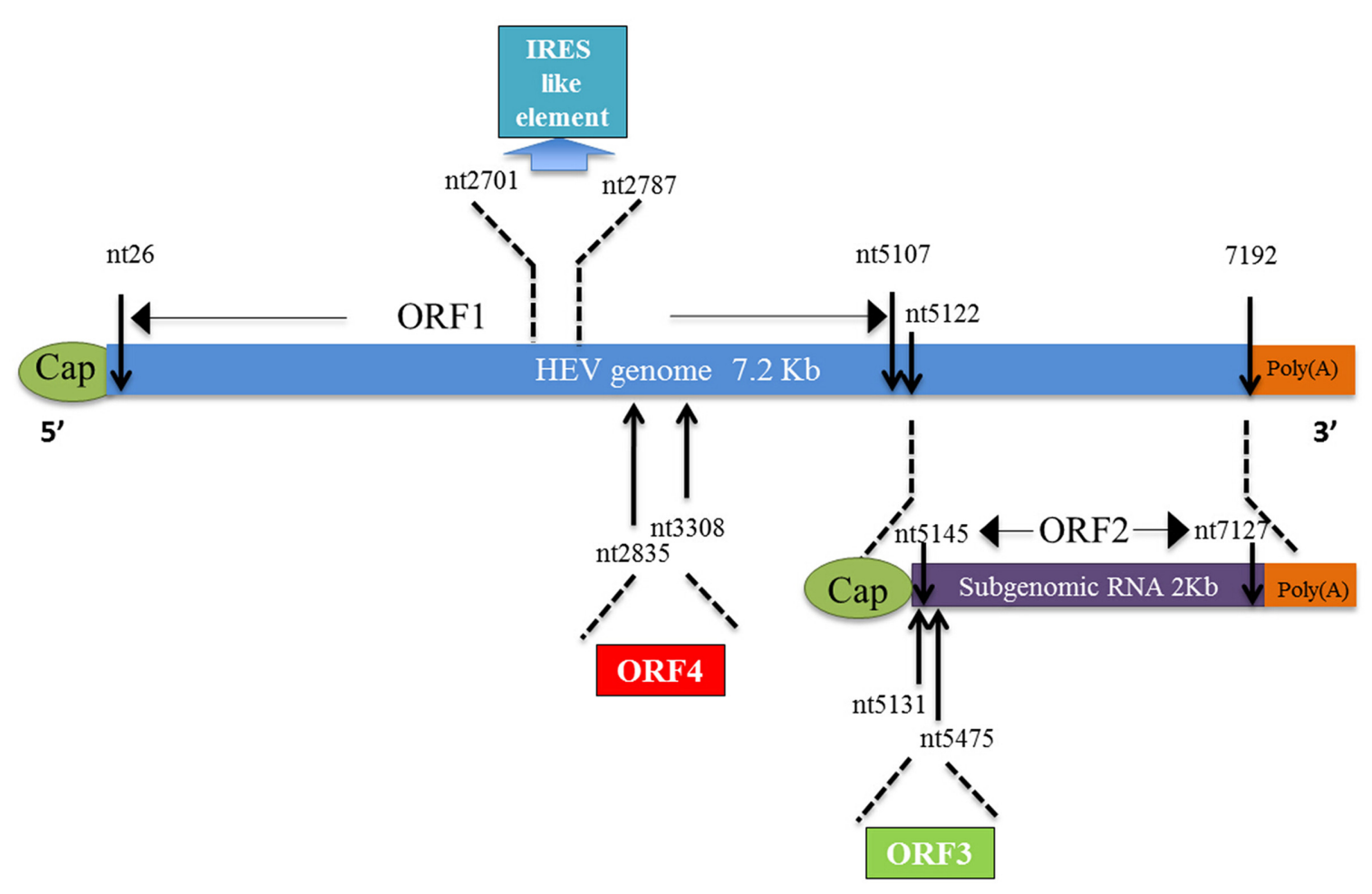

FIGURE 1 | Schematic illustration of hepatitis E virus (HEV) genome, subgenomic RNA, and ORFs. ORF1 (nt 26-5107) is labeled above the genomic RNA box. ORF2 (nt 5145-7127) and ORF3 (nt 5131-5475) are encoded by the same subgenomic RNA. The newly identified ISRE like sequence (nt 2701-2787) and ORF4 (nt 2835-3308) which are overlapped with ORF1 are listed as well. Moreover, the numbers above or below the RNA boxes indicate nucleotide numbers of the cDNA of HEV Sar55 (GenBank accession number AF444002) genomic RNA.

The genotypes that infect humans include $1,2,3,4$, and 7 (Table 1; Smith et al., 2016).

Hepatitis E virus-like virus isolated from avian species is called avian $\mathrm{HEV}$, which shares less than $50 \%$ nucleotide identity but common antigen epitopes in the capsid protein with mammalian HEV (Haqshenas et al., 2001, 2002; Huang et al., 2004). Currently, avian HEV is classified into the species Orthohepevirus B (Smith et al., 2014). HEV strains from rat, ferret and bat are classified into the species of Orthohepevirus $C$ and $D$, respectively (Smith et al., 2014). The cutthroat trout virus (CTV) is identified as an HEV-like virus in retrospective studies. CTV shares even lower sequence identity with mammalian and avian HEV and is now classified as a member of the genus Piscihepevirus (Batts et al., 2011; Smith et al., 2014).

For the four genotypes (1-4) of HEV infecting humans, there are differences in their geographic distributions. Genotype 1 $\mathrm{HEV}$ mainly includes strains from Asia and Africa including the Sar55 isolate, while genotype 2 contains a Mexican strain and

TABLE 1 | Hepatitis E virus (HEV) genotypes, natural hosts, and zoonotic infection to humans.

\begin{tabular}{|c|c|c|c|c|}
\hline Genus & Species & Genotype & Natural hosts & Infection to humans \\
\hline & & 2 & Human & Yes \\
\hline & & 4 & Human, pig, yak, wild boar & Yes \\
\hline & & 5 & Wild boar & Unknown \\
\hline & & 6 & Wild boar & Unknown \\
\hline & Orthohepevirus B & & Chicken & No \\
\hline & Orthohepevirus C & $\mathrm{C} 1$ & Rat & No \\
\hline & & $\mathrm{C} 2$ & Ferret & No \\
\hline & Orthohepevirus D & & Bat & No \\
\hline Piscihepevirus & Piscihepevirus A & & Trout & No \\
\hline
\end{tabular}


variants from Africa. Genotypes 3, including human and swine $\mathrm{HEV}$, is mainly found in the industrialized countries (Purcell and Emerson, 2008). The genotype 4 is previously thought to be found only in China (Purcell and Emerson, 2008), however, recent reports show that genotype $4 \mathrm{HEV}$ strains are also isolated in other countries, including India, Indonesia, Japan, Vietnam, Spain, France, and Italy (Okamoto, 2007; Midgley et al., 2014; Lapa et al., 2015). For details about molecular epidemiology and viral evolution of HEV, please refer to the article by Purdy and Khudyakov (2011).

\section{VIRAL PROTEINS OF HEV AND THEIR FUNCTIONS}

\section{ORF1-Encoded Polyprotein}

The ORF1 is the largest ORF in the HEV genome and has $5082 \mathrm{nt}$ in length according to the Sar55 strain (Tsarev et al., 1992; Emerson et al., 2001). It starts at the $5^{\prime}$ end of the genome after a $25 \mathrm{nt}$ non-coding region and can be translated directly from the HEV genome. ORF1 encodes a 1693 amino acid (aa) polyprotein, which is needed for HEV replication. Bioinformatics analysis for the protein sequence encoded by ORF1 found eight putative domains according to their similarity to counterparts in the other viruses (Koonin et al., 1992). Moreover, the ORF1 sequence is highly related to the group of Rubi-like viruses including Rubivirus, Betatetravirus, Benyvirus, and Omegatetravirus (Koonin and Dolja, 1993; Liu et al., 2009). These functional domains include methyltransferase domain (Met), Y domain (Y), papain-like cysteine protease (PCP or $\mathrm{PLP}$ ), hypervariable region (HVR), proline-rich region (Pro), $\mathrm{X}$ domain, helicase domain (Hel) and RdRp (Figure 2). In recent publications, the proline-rich region is frequently named together with HVR as the HVR.

The current data are conflicting about whether the HEV ORF1 product functions as a single polyprotein or needs to be further processed into smaller units by viral or cellular proteases (Ansari et al., 2000; Ropp et al., 2000; Sehgal et al., 2006; Suppiah et al., 2011; Perttila et al., 2013). One study using a vaccinia-derived expression system demonstrated that the ORF1 polyprotein could be cleaved by the PCP within it (Ropp et al., 2000). More than 10 years after that publication, the same group showed a lack of processing of the ORF1 polyprotein in HEK293T cells (Suppiah et al., 2011). Two fragments were found in another study on in vitro translation of full-length ORF1, but they were not observed in pulse-chase assay in human cells and their production was not dependent on the predicted protease domain in ORF1 product (Perttila et al., 2013). Furthermore, in Escherichia coli and a cell-free system based on HepG2 cells, ORF1 was expressed as a $186 \mathrm{kDa}$ protein without further processing detected (Ansari et al., 2000).

On the other hand, other studies demonstrated contrasting results. Transfection of HepG2 cells with in vitro transcribed RNA from HEV cDNA produced cleaved products with sizes of 35,38 , and $36 \mathrm{kDa}$ for the Met, Hel, and RdRp domains, respectively (Panda et al., 2000). Another study focusing on the analysis of the ORF1 functional domains also observed proteolytic processing of the HEV ORF1 fragment in insect cells (Magden et al., 2001). In a later study, the ORF1 product expressed in insect cells by baculovirus expression system was shown to exist as smaller fragments and this proteolytic processing could be inhibited by E-64d, a cell-permeable cysteine protease inhibitor (Sehgal et al., 2006). A recent publication reported that the refolded PCP domain expressed in E. coli is able to process ORF1 polyprotein in vitro (Paliwal et al., 2014). Moreover, based on an HEV-Sar55 replicon system in S10-3 cells (a subclone of Huh7 cells with improved HEV replication; Graff et al., 2006), the putative catalytic aa residues in the ORF1 protease domain are indispensable for HEV replication (Parvez, 2013). Overexpression of ORF1 from HEV Sar55 strain in S10-3 cells also resulted in cleaved products (Parvez, 2013).

Thus, despite the lack of conclusive data, the majority of studies so far are in favor of the polyprotein proteolysis. The cleaved ORF1 products could be possibly detected in the HEVinfected cells if effective and specific antibodies against the domains are available. A recent study employing yeast two hybrid $(\mathrm{Y} 2 \mathrm{H})$ demonstrated intraviral interactome within the domains from ORF1, further supporting the proteolysis of ORF1 polyproteins (Osterman et al., 2015). Moreover, ORF1 could be a determining factor for host tropism as a recombinant HEV harboring ORF1 of a genotype $4 \mathrm{HEV}$ strain and the rest genome from genotype 1 strain replicates in transfected porcine kidney cells (Chatterjee et al., 2016). Therefore, ORF1 products involve in determination of HEV host tropism and should be further investigated. It is possible that proline rich region or HVR may be involved in host tropism determination since other domains are more conserved among the four HEV genotypes.

\section{Met Domain}

The Met domain is the first one at the N-terminus of the ORF1-encoded polyprotein. As the HEV genome is capped and the capping is crucial for its infectivity, a viral-specific

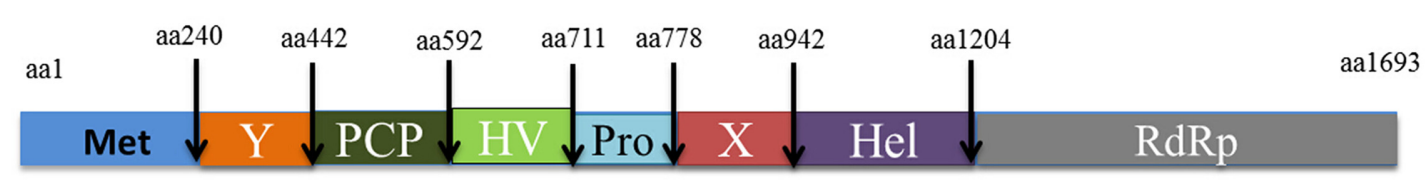

FIGURE 2 | Schematic illustration of putative domains in ORF1 polyprotein. Met: Methyltransferase domain; Y: Y domain; PCP: papain-like cysteine protease; HV: hypervariable region; Pro: proline-rich domain; X: X-domain; Hel: helicase; RdRp: RNA-dependent RNA polymerase. The numbers above the box indicate amino acid residues of ORF1-encoded polyprotein of Sar55 strain. 
methyltransferase was expected (Emerson et al., 2001; Zhang et al., 2001). Based on sequence analysis, the region in aa residues 60-240 was assumed to be a putative methyltransferase (Koonin et al., 1992). The HEV Met domain is similar to that of Tricornaviruses, which belong to the alpha-like supergroup of RNA viruses (van der Poel et al., 2001). There are an invariant His residue, an AspXXArg signature and an invariant Tyr residue in methyltransferase motifs I, II, and IV, respectively (Rozanov et al., 1992). Expression of HEV ORF1 cDNA (aa residues 1-979) in insect cells yields a $110 \mathrm{kDa}$ protein (P110), along with a $80 \mathrm{kDa}$ protein that is believed to be the proteolytic product of P110 (Magden et al., 2001). In vitro assays shows that the P110 possesses guanine-7-methyltransferase and guanylyl transferase activity (Magden et al., 2001).

\section{Y Domain}

The second domain after the methyltransferase is the $\mathrm{Y}$ domain, which is assumed to start from aa residue 216 and ends at aa 442 . It is highly similar to that of the rubella virus (Koonin et al., 1992). Currently, there is no information available for the function of this Y domain in either HEV or the rubella virus.

\section{PCP Domain}

Papain cysteine protease domain is downstream of the $\mathrm{Y}$ domain. The PCP domain demonstrates moderate similarity to the protease domain in the rubella virus (Koonin et al., 1992). In the rubella virus, the PCP domain is responsible for the proteolytic processing of its NSP (Marr et al., 1994). Mutation of the catalytic residue within the PCP (Cys1152) abolishes its protease activity and results in inhibition of the NSP processing. It is also involved in trans and cis cleavage of the rubella virus NSP (Liang et al., 2000). However, regarding the function of the HEV PCP domain, the current data are incomplete and controversial.

In the vaccinia-mediated ORF1 expression system, mutation of the putative catalytic core (Cys483) of HEV PCP had no effect on proteolytic processing of the ORF1 product (Ropp et al., 2000). Another putative catalytic site of His590 in PCP is not conserved among different HEV strains. Later studies showed controversial data for the processing of the HEV ORF1 product (Ansari et al., 2000; Ropp et al., 2000; Sehgal et al., 2006; Suppiah et al., 2011). This leads to the speculation that whether HEV PCP is a real cysteine protease. Recently, Parvez demonstrated that the mutation of six cystine residues (C457A, C459A, C471A, C472A, C481A, C483A) and three histidine residues (H443L, H497L, H590L) in the PCP domain completely abolished HEV RNA replication in a Sar55-based replicon system in S10-3 cells. Notably, of these essential Cys and His residues, C483 and H590 were previously predicted as putative catalytic residues in the PCP domain (Parvez, 2013). Furthermore, the PCP domain expressed in the E. coli C43 strain (resistant to toxic protein expression) possesses protease activity (Paliwal et al., 2014). The purified protein cleaves both HEV ORF1 and ORF2 products that are in vitro translated. Protease inhibitor assay indicates the HEV PCP domain is a chymotrypsin-like protease (Paliwal et al., 2014). This observation suggests that HEV PCP is a real protease for HEV ORF1 polyprotein processing.
In recent years, the connection between ubiquitination and innate immunity signaling has been demonstrated (Zeng et al., 2009; Mao et al., 2010; Liu et al., 2013), and the antiviral function of some ubiquitin-like molecules, such as interferon-stimulated gene 15 (ISG15) and small ubiquitin-like modifier (SUMO), has been described (Liu et al., 2013). Some studies indicate that viral coded cysteine proteases possess deubiquitinase activity to inhibit host innate immunity, such as arterivirus papain-like protease 2 (van Kasteren et al., 2013) and PCP from porcine reproductive and respiratory syndrome virus (PRRSV; Li et al., 2010; Sun et al., 2010). Similar research performed on the HEV PCP domain suggests that it acts as an antagonist to ISG15 function to inhibit host innate immunity when expressed together with Met as the Met-PCP protein (Karpe and Lole, 2011). Moreover, study from our laboratory demonstrated that the PCP domain from HEV genotype 1 Sar55 strain is able to inhibit ubiquitination of RIG-I and TBK1, therefore resulting in the inhibition of RIG-I mediated signaling in innate immune responses (Nan et al., 2014b).

\section{HVR Domain}

Between the PCP domain and the X domain, there are HVR and Pro domains. These two regions were first named as HVR due to the extreme divergence in sequence between nt 2011 and 2325 (corresponding to residues aa 662-766) when the HEV Sar55 was compared with two other strains (Tsarev et al., 1992). In a later study, aa 712-778 in this region were designated a prolinerich region, which could be found in rubella virus as well. It was also considered to serve as a hinge between the $\mathrm{X}$ domain and its upstream domains because multiple proline residues in a protein or polypeptide may result in an unstable tertiary structure (Koonin et al., 1992; Tsai et al., 2001; Dosztanyi et al., 2006; Dunker et al., 2008). The length and sequence of HVR and Pro is highly variable among different HEV strains (Pudupakam et al., 2009; Smith et al., 2013).

Currently, there is some confusion regarding the nomenclature of those two regions. Some of the recent publications designated the region of aa $712-778$ as the hypervariable domain, which was originally referred to proline-rich region and left out the immediately upstream domain (aa 592-711; Pudupakam et al., 2009, 2011), whereas others still designate the aa 712-778 as the proline-rich region (Purdy, 2012). Current research mainly focuses on the Pro region and pays less attention to the upstream HVR domain. As a result, the function of HVR is unknown. However, data gained from the rubella virus shows that deleting part of the HVR domain along with part of the Pro region renders the mutant non-viable (Tzeng et al., 2001).

\section{Pro Domain}

The Pro domain is considered to be an intrinsically disordered region (IDR) with flexibility for insertion and deletion (Purdy, 2012; Purdy et al., 2012). Data from its counterpart in the rubella virus indicates that this region is not required for viral replication (Tzeng et al., 2001). As expected, deletion and mutation of this region in HEV indicates that it is not required for viral replication and infectivity, but it plays a role in replication efficiency in vitro (Pudupakam et al., 2009, 2011). It was also demonstrated that the Pro domain is interchangeable between 
genotypes with genotype-specific differences (Pudupakam et al., 2011). More interestingly, a remarkable HEV strain Kernow-C1, which was originally isolated from an HIV-positive patient with chronic HEV infection, contains an insertion of a $174 \mathrm{nt}$ gene fragment of human ribosomal protein S17 in the Pro region (Shukla et al., 2011). This recombinant virus was adapted in culture cells and is able to propagate in cells from different species. It was speculated that insertion of the S17 fragment occurred in the host but was selected in cultured cells. This speculation needs further verification as direct detection of the inserted fragment from the host sample was not successful. Experimental insertion of the S17 fragment into the Pro domain of the Sar55 strain also generated a viable chimeric virus (Shukla et al., 2011). The S17 sequence insertion in HEV correlates with novel nuclear/nucleolar trafficking capabilities to the ORF1 protein of HEV Kernow C-1 P6 and the enhanced replication of this strain (Kenney and Meng, 2015a,b).

Although the Pro domain is considered highly diverse, some motifs are found in the IDR. Based on computer analysis and comparison with other IDRs, Purdy et al. identified several linear motifs (LMS), including two protease cleavage sites, three ligand binding sites and two kinase phosphorylation sites across all four genotypes (Purdy et al., 2012). The putative protein-protein interactions of the Pro domain were proposed in the same report as well, but need experimental verification. Nevertheless, this report provides some assumptions about the disorder-to-order state of the Pro domain. In another study, alignment of the Pro domain from different genotypes indicated the sequence is more conserved in genotypes 1 and 2 than genotypes 3 and 4 (Purdy, 2012). Adaptation to a wide host range for genotypes 3 and 4 is a possible reason. The authors also assessed the diversity of the Pro domain due to the higher rate of substitutions at the first and second codon positions, leading to a shift in translation to be more proline, alanine, serine, and threonine rather than histidine, phenylalanine, tryptophan, and tyrosine. This pattern matches the aa usage in proline-rich IDRs (Purdy, 2012). Furthermore, the $\mathrm{C}$-terminus of this domain can tolerate more mutations than the N-terminus. Recently, the heterogeneity of the Pro and X domains is implicated in HEV persistence, which was revealed in an investigation into the association between the genetic heterogeneity of HEV quasispecies in ORF1 and the outcome of infection in solid-organ transplant patients (Lhomme et al., 2014).

\section{$X$ Domain}

The $\mathrm{X}$ domain is located immediately downstream of the Pro domain. In HEV, its function is unknown. The HEV X domain homologs in other viruses such as rubella virus, alpha virus and coronavirus, are commonly identified as domain flanking the PCP domain (Gorbalenya et al., 1991; Koonin et al., 1992). It is also known as macro domain, due to its similarity with non-histone domain of the histone macroH2A. Macro domain has been identified in a variety of bacterial, archaeal, and eukaryotic organisms (Pehrson and Fried, 1992; Pehrson and Fuji, 1998).

Early studies of the human macro domain indicate that it is enriched in inactive mammalian $\mathrm{X}$ chromosomes, suggesting a role in gene silencing and inactivation (Costanzi and Pehrson, 1998). The macro domain inhibits transcription and binds to the transcription activator NF- $\mathrm{kB}$ (Perche et al., 2000; Angelov et al., 2003). Crystal structure analysis identifies a DNA binding motif in the macro domain, suggesting that it might interact with nucleic acids (Allen et al., 2003). A biochemical functional analysis indicates that the macro domain is involved in the downstream processing of ADP-ribose $1^{\prime \prime}$-phosphate, a side product of cellular pre-tRNA splicing (Martzen et al., 1999). Furthermore, the macro domain is found in association with proteins involved in poly(ADP-ribose) polymerization, ADPribosylation and ATP-dependent chromatin remodeling (Aguiar et al., 2005).

Information about the function of viral macro domains is limited. ADP-ribose $1^{\prime \prime}$-phosphatase activity has been demonstrated in the macro domain from coronavirus (Martzen et al., 1999; Putics et al., 2005, 2006; Saikatendu et al., 2005). Crystal structure analysis and in vitro assays on the macro domain of the SARS virus indicate that the viral macro domain has relatively poor ADP-ribose $1^{\prime \prime}$-phosphohydrolase activity, but can bind free ADP-ribose and poly(ADP-ribose) efficiently (Egloff et al., 2006). In another report, the macro domains from Semliki Forest virus, HEV, SARS virus and yeast were compared with the human macro domain (Neuvonen and Ahola, 2009). The viral macro proteins bind poly (ADP-ribose) and poly (A), but have a low affinity for monomeric ADP-ribose. This implies that viral macro domains are functionally different from human homolog and may participate in cellular pathways involving RNA rather than ADP-ribose derivatives. However, a recent study shows that viral macro domains (HEV, coronavirus, and venezuelan equine encephalitis virus) can reverse protein ADP-ribosylation by acting on ADP-ribosylated substrates through the hydrolytic activity of their macro domains (Li et al., 2016). Furthermore, other studies indicate that the expression of viral macro domain in liver cells inhibits apoptosis since it is functionally related to poly(ADP-ribose) polymerase-1 (PARP-1; Allen et al., 2003; Chen et al., 2009), suggesting a role in apoptosis during viral infection. Recently, a highly conserved "glycinetriad" (Gly815-Gly816-Gly817) was identified downstream of the macro domain of HEV, which is homologous to the rubella virus protease-substrate (G1299-G1300-G1301; Parvez, 2013). Mutagenesis study indicates that G816V and G817V mutations in the macro domain are lethal for Sar55 replication in S10-3 cells. Further analysis identified the $\mathrm{N}$-terminus residues Asn806, Asn809, His812, Gly815-Gly816-and Gly817 formed a potential catalytic-site homolog of Coronavirus ADP-ribose$1^{\prime}$-monophosphatase, which has essential role in viral replication (Parvez, 2015a). As mentioned above, a recent report suggests that the quasispecies heterogeneity in the macro domain might facilitate HEV persistence in solid-organ transplant patients (Lhomme et al., 2014). Study from our laboratory demonstrates that X domain of HEV Sar55 strain inhibits the phosphorylation of IRF3, which is a key transcription factor for type I IFN induction (Nan et al., 2014b). Moreover, except interacting with light chain subunit of human ferritin and inhibiting ferritin secretion, the X domain interacts with HEV Met and VP13 (Anang et al., 2016; Ojha and Lole, 2016). 


\section{Helicase Domain}

The RNA helicase domain is downstream of the X domain. It is encoded by many positive-stranded RNA viruses and is essential for their replication (Kadare and Haenni, 1997). Helicases are motor proteins that are able to unwind nucleic acid strands by using energy from ATP hydrolysis (Kadare and Haenni, 1997). Helicases can be divided into six superfamilies (SF1-6; Singleton et al., 2007). RNA virus coded helicases are mainly classified into SF1 and SF2. Helicases SF1 and SF2 contain seven signature motifs (I, Ia, II, III, IV, V, and VI) that form the core of the enzyme (Kadare and Haenni, 1997). The HEV helicase belongs to helicase superfamily SF1 and is proposed to possess both NTPase and RNA unwinding activities (Koonin et al., 1992; Kadare and Haenni, 1997). In vitro experiments demonstrate that the HEV helicase purified from $E$. coli expression has both of the activities. It drives the hydrolysis of rNTPs but also dNTPs at a lower efficiency, as well as unwinds RNA duplexes with $5^{\prime}$ overhangs (Karpe and Lole, 2010a). RNA 5' -triphosphatase activity has also been observed in the HEV helicase domain, which is proposed to function along with methyltransferase for catalyzing RNA capping (Karpe and Lole, 2010b). Recently, a mutagenesis study on HEV helicase demonstrated that motifs I, IV, and VI are dispensable, while motifs I and III are crucial and unique for HEV helicase function (Mhaindarkar et al., 2014). A recent study shows that a V239A substitution in the helicase domain of a swine HEV strain is potentially associated with increased virulence (Ward et al., 2015). However, no human infection was reported to be associated with this strain.

\section{RdRp Domain}

The last domain of HEV ORF1 polyprotein is the RdRp. All positive-stranded RNA viruses code an RdRp, which is necessary for viral replication (O'Reilly and Kao, 1998). The RdRp from all positive-sense RNA viruses are classified into three large supergroups. All RdRp domains contain approximately 300 amino acid residues, with the central and C-terminal parts showing high similarity between each other (Koonin, 1991). RdRp from HEV belongs to supergroup III and has the highest similarity to the domains in rubella virus and beet necrotic yellow vein virus (BNYVV; Koonin et al., 1992). All eight conserved motifs can be found in HEV RdRp, including an $\mathrm{Mg}^{2+}$ binding sequence (GDD), which is essential for RdRp activity. The purified HEV RdRp is able to bind the $3^{\prime}$ end of HEV RNA, and needs two stem-loop structures at the $3^{\prime}$ end of the poly(A) stretch for this binding (Agrawal et al., 2001). Expression of the RdRp in mammalian cells as a GFP fusion protein indicates that it localizes in endoplasmic reticulum (ER), which could be a potential replication site for HEV (Rehman et al., 2008). Recent studies indicate that the emergence of G1634R mutation in the HEV RdRp is possibly due to ribavirin-induced mutagenesis and is associated with treatment failure of ribavirin monotherapy in solid-organ transplant patients (Debing et al., 2014b; Lhomme et al., 2015; Todt et al., 2016).

\section{The Capsid Protein Encoded by ORF2}

The capsid protein is the major component of HEV virions. ORF2 is 1983 nt in length beginning from 37 nt downstream of
ORF1 and ending at $65 \mathrm{nt}$ upstream of the poly-A tail (Reyes et al., 1993; Figure 1). The deduced full-length ORF2 product has 660 aa residues with a predicted molecular mass of $72 \mathrm{kDa}$ (Robinson et al., 1998). Recombinant ORF2 protein can bind to the $5^{\prime}$ region of $\mathrm{HEV}$ genome (Surjit et al., 2004). It was first shown that the ORF2 product exists as an $88 \mathrm{kDa}$ protein, which carries N-terminal linked glycans and a potential ER-directing signal about 15 aa from its $\mathrm{N}$ terminus (Jameel et al., 1996). This $88 \mathrm{kDa}$ protein can be further processed and has the potential to form non-covalent homodimers. A further study from the same group demonstrated Asn310 in ORF2 product to be the major site for glycosylation (Zafrullah et al., 1999; Figure 3). A mutagenesis study indicated that the $\mathrm{N}$-terminal signal peptide is required for its cell surface expression via ER transition, but glycosylation of the capsid protein is not required (Zafrullah et al., 1999).

Since glycosylation of the capsid protein in non-enveloped viruses is not common, it is not known whether these modifications have biological significance for $\mathrm{HEV}$ infection. Mutations in the putative glycosylation sites (aa 137, aa 310, aa 562) prevent formation of viral particles and infection of rhesus macaques but without an effect on genome replication in cells (Graff et al., 2008). Mutation in the first two glycosylation sites prevents virion assembly, while mutation of the third site allows virion particle formation and RNA encapsulation (Graff et al., 2008). HEV particles released from cultured cells have a lipid component (quasi-enveloped), which can be removed by detergent treatment (Qi et al., 2015). The relationship between glycosylation of ORF2 and lipid envelope of viral particles needs to be clarified.

On the other hand, data acquired from studies using insect cells provide a different conclusion regarding ORF2 expression and processing. When expressed in insect cells, ORF2 product can be an insoluble full length protein of about $72 \mathrm{kDa}$, and a soluble form of $56.5 \mathrm{kDa}$, a processed product of the intact form (McAtee et al., 1996). Another group shows that when ORF2 is expressed in SF9 cells, a $62 \mathrm{kDa}$ product is detected while lacking the first 111 aa residues of the putative ORF2 polypeptide (Zhang et al., 1997). Further studies in two different insect cell lines (SF9 and Tn5) show a soluble form of ORF2 product with a molecular mass of $50 \mathrm{kDa}$, which lacks the first 111 aa and the last 52 aa of ORF2 polypeptide but retains the ability to form virus-like particles (VLPs; Li et al., 1997, 2005d). VLP assembly is thought to involve dimer formation, and the C-terminus of the recombinant ORF2 protein is believed to be responsible for homo-oligomerization (Tyagi et al., 2001a; Xiaofang et al., 2001; Li et al., 2005a). A 3.5- $\AA$ resolution crystal structure obtained from HEV VLP indicates that the truncated HEV capsid protein has three domains designated as S (shell, aa 129319), M (middle, aa 320-455), and P (protruding, aa 456-606; Yamashita et al., 2009; Figure 3). The VLP is composed of 60 subunits of the truncated capsid protein, forming icosahedral 2, 3, and 5-fold axes (Yamashita et al., 2009). Mutational analyses indicate that the protruding domain is involved in binding to the susceptible cells and contains neutralization epitopes (Yamashita et al., 2009). Moreover, the HEV VLP can be used as a delivery system to display foreign epitopes on its surface (Xing et al., 2011). 


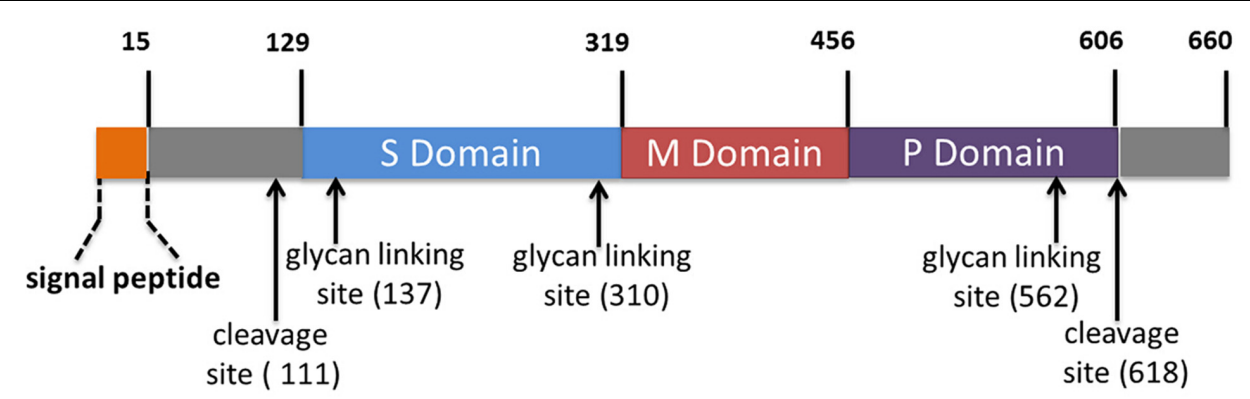

FIGURE 3 | Schematic illustration of the domains of the HEV capsid protein encoded by ORF2. The numbers above the box and those in parentheses indicate amino acid residues of the capsid protein. S domain: shell domain; M domain: middle domain; P domain: protruding Domain.

The ORF2 product expressed in insect cells is reactive with anti-HEV antibodies (Tsarev et al., 1993). Genetic analysis of ORF2 showed over $85 \%$ similarity among the four major HEV genotypes in mammalian hosts (Mori and Matsuura, 2011). Amino acid alignment indicates that divergences are mainly in the first 111 aa of the $\mathrm{N}$ terminus, which is not a component of the virions (Mori and Matsuura, 2011). A study manipulating a phage display system for overlapping peptides and truncated ORF2 proteins maps the major neutralizing domain to residues 458-607, which matches the location of the P domain (Schofield et al., 2000; Meng et al., 2001; Zhou et al., 2004). Both conformational and linear neutralizing epitopes have been identified from the HEV capsid protein (Gu et al., 2015; Tang et al., 2015).

These data provide valuable information for vaccine development. The ORF2 truncated proteins generated by baculovirus or bacterial expression systems have been tested in clinical trials (Shrestha et al., 2007; Zhu et al., 2010). However, a recent study that evaluated cross-protection against heterologous $\mathrm{HEV}$ indicates that vaccination of pigs with truncated capsid proteins derived from swine, rat and chicken $\mathrm{HEV}$ only elicits partial protection against a genotype 3 mammalian HEV (Sanford et al., 2012). Study of avian HEV capsid protein indicates that the $\mathrm{N}$-terminal 338 aa residues react with swine and human anti-HEV sera (Wang et al., 2014b). Moreover, a recent study suggests that antigenic composition and immunoreactivity differed between HEV recombinant capsid proteins from different genotypes (Behloul et al., 2015), which raises the concerns about the efficacy of the current HEV subunit vaccine marketed in China. On the other hand, experiments based on the newly identified quasi-enveloped HEV particles indicate that lipid membrane protects the virions from neutralizing antibodies against the capsid protein (Yin et al., 2016).

Additionally, as a structural protein, the HEV capsid protein has been found to interact with some cellular proteins and plays a role in cell signaling. In one study, the capsid protein activates the pro-apoptotic gene CHOP, and increases the expression of HSP72, HSP70B and HSP40, and interacts with HSP72 (John et al., 2011). In addition, the capsid protein interacts with $\beta$-TRCP, a component of the ubiquitination complex that inhibits I $\mathrm{B} \alpha$ ubiquitination-mediated NF- $\kappa \mathrm{B}$ activation (Surjit et al., 2012). However, these data are all based on overexpression of
ORF2 in mammalian cells, and need to be further verified in whole virus infection.

\section{ORF3-Encoded Protein VP13}

The ORF3 is the smallest among the three ORFs of HEV and overlaps with ORF2 by approximately $300 \mathrm{nt}$ in a different reading frame. However, it does not overlap with ORF1 (Graff et al., 2006). The overlapping region with ORF2 (nt 5145-5475) was found to be the most conserved region between the Sar55 and BUR121 strains (Tsarev et al., 1992). An early study proposed that ORF3 encodes a protein with 123 aa and comes from a different subgenomic RNA other than that encoding ORF2 (Tam et al., 1991). However, a later study based on an HEV replicon shows that ORF3 is translated from the bicistronic subgenomic RNA and initiates at the third AUG of the presumed ORF3 at nt 5131 for Sar55 and the product is a protein with 113 or 114 aa and molecular size of $13 \mathrm{kDa}$ (VP13), which is 9 aa shorter than the earlier predicted version (Graff et al., 2006). This observation has been confirmed by another study using a different HEV strain (Huang et al., 2007).

Sequence analysis has indicated that VP13 is unique and has no similarity to any other proteins known. It contains two hydrophobic domains in its $\mathrm{N}$-terminal half and two proline-rich domains in its C-terminal portion (Kannan et al., 2009; Holla et al., 2013). A phosphorylation site (Ser71) was identified in the first proline-rich domain and can be phosphorylated by MAP kinase (Zafrullah et al., 1997). Furthermore, two PSAP motifs have been identified in genotype 3 VP13, with the first PSAP motif located at aa 86-89 and the second at aa 95-98, whereas genotypes 1, 2, and 4 have only one PSAP motif at aa 95-98 (Nagashima et al., 2011b). The second PSAP motif is needed for $\mathrm{HEV}$ virion release. Interestingly, among the four genotypes that infect humans, only genotype 1 vp13 has an additional prolinerich region that contains a PXXP motif in aa 66-75, which is linear and surface-oriented (Nan et al., 2014a,b, 2015). The unique motif reacts with a genotype 1 VP13-specific monoclonal antibody. This proline-rich region contains residues PMSPLR, a typical motif $(\mathrm{PXXPX}+)(+$ is either arginine or lysine, $\mathrm{X}$ can be any aa) for class II SRC homology 3 (SH3) domains. $\mathrm{SH} 3$ domains are known to bind to proline-rich sequences containing a core PXXP motif flanked by a positively charged residue (Baumann et al., 1998; Raeder et al., 1998). SH3 domains 
comprise of about 60 residues and proteins containing $\mathrm{SH} 3$ domains typically play a role in signaling pathways involved in cell growth, differentiation and other regulatory functions (Zarrinpar et al., 2003). The next proline-rich region spanning aa 95-102 are RPSAPPLP, containing an additional residue than the typical motif (+XXPXXP) for class I SH3 domains. But interestingly only the PXXP motif in the second proline-rich region is known to interact with $\mathrm{SH} 3$ domains (Korkaya et al., 2001). The function of the PXXP motif in the first proline-rich region (aa 66-75) of VP13 of genotype $1 \mathrm{HEV}$ is unknown. It might play a role in cellular signaling as proline-rich motifs are also involved in interacting with other domains besides $\mathrm{SH} 3$ (Zarrinpar et al., 2003).

Although the full function of HEV VP13 has not been defined yet, some studies have suggested that VP13 plays multiple roles during HEV infection. Early studies focusing on VP13 antigenicity and epitope mapping demonstrated that the last 32 aa of VP13 are an immunodominant region, and a synthesized peptide from that region is reactive with anti-HEV serum from a recovered patient (Semiletov et al., 1995; Dement'eva et al., 1997). However, another study mapping the $\mathrm{T}$ cell epitopes in ORF2 and ORF3 products indicated that no $\mathrm{T}$ cell proliferation was observed when cells were stimulated with peptides from VP13 (Aggarwal et al., 2007). A recent study based on genotype $4 \mathrm{HEV}$ shows that continuous amino acid motif, VDLP, at the C-terminus of genotype $4 \mathrm{HEV} \mathrm{VP13,} \mathrm{is} \mathrm{a} \mathrm{core} \mathrm{sequence} \mathrm{of} \mathrm{a}$ VP13 epitope (Wang et al., 2015). Although VP13 is dispensable for viral replication in cultured cells (Emerson et al., 2006), it is indispensable for HEV infection in vivo, implying an important role for VP13 in host invasion (Graff et al., 2005; Huang et al., 2007).

A yeast two-hybrid system is employed to screen for the interaction partners for VP13. The VP13 can bind to inactive mitogen-activated protein kinase (MAPK) phosphatase and lead to activation of the MAPK (Kar-Roy et al., 2004), suggesting that VP13 can modulate host gene expression since MAPK is related to cell signaling and gene expression. Another study shows that VP13 inhibits the nuclear translocation of STAT3 and down-regulates STAT3-mediated gene expression, such as acute-phase response proteins (Chandra et al., 2008). The VP13 can also increase the expression of glycolytic pathway enzymes by increasing the phosphorylation and transactivation activity of p300/CBP (Moin et al., 2009). Furthermore, microarray analysis of Huh7 cells with VP13 expression suggests that liver-specific genes can be modulated, as VP13 is able to modulate the phosphorylation of hepatocyte nuclear factor 4 (Chandra et al., 2011).

The VP13 can also up-regulate mitochondrial voltagedependent anion channel genes, which can protect cells from mitochondrial depolarization and death (Moin et al., 2007). This result implies that VP13 is able to inhibit the mitochondrial apoptosis pathway. The pro-survival role of VP13 is also demonstrated in another study showing VP13 delays the trafficking and degradation of the activated hepatocyte growth factor receptor to prolong endomembrane growth factor signaling (Chandra et al., 2010). Additional interacting molecules have been identified for VP13 by yeast two-hybrid screens, including $\alpha$-1-microglobulin, bikunin, and bikunin precursor protein (AMBP), fibrinogen $\beta$ chain and hemopexin (Tyagi et al., 2004, 2005; Ratra et al., 2008, 2009). Moreover, a recent study screening for intraviral protein interactions identified the Met, PCP, X, Helicase, and RdRp domains as interacting partners for VP13 as well (Osterman et al., 2015).

Besides yeast two-hybrid screens, overexpression of VP13 coding plasmid in mammalian cells was also employed to elucidate the function of VP13. The VP13 associates with the cytoskeleton fraction when expressed in cells, and deletion of the N-terminal hydrophobic domain of VP13 abolishes this association (Zafrullah et al., 1997). In a more detailed study, GFP-tagged VP13 is found to interact with microtubules to form a filamentous pattern in cells and modulate the microtubule dynamics (Kannan et al., 2009). VP13 leads to an elevation of acetylated $\alpha$-tubulin, indicating increased microtubule stability (Kannan et al., 2009). Since there are two hydrophobic domains located in the N-terminus of VP13, truncation analysis indicated that both the hydrophobic domains are required for its association with the microtubules. Moreover, salt extraction studies have suggested that the VP13-microtubule interaction is electrostatic and motor protein dynein is needed for the interaction (Kannan et al., 2009). An earlier study showed that VP13 cannot be co-precipitated with tubulin by anti-tubulin antibody (Zafrullah et al., 1997). These results suggest that VP13 may associate with microtubules through interaction with another protein. This microtubule-like distribution of VP13 suggests that it may play a role in promoting virus egress, as the pUL37 protein of herpesvirus can interact with dystonin, an important cytoskeleton cross-linker involved in microtubulebased transport, in order to promote capsid transport on microtubules during egress (Pasdeloup et al., 2013). Besides cellular proteins, VP13 has been shown to interact with viral helicase, PCP and methytransferase from HEV ORF1, which suggests a regulatory function for VP13 in orchestrating the formation of the replicase complex (Osterman et al., 2015).

More interestingly, another study using monoclonal antibody against VP13 to capture HEV particles showed that VP13 can associate with virions and support virus release (Takahashi et al., 2008). The requirement of VP13 for virion release was later confirmed by a cell culture-adapted genotype $3 \mathrm{HEV}$ strain with VP13 deletion (Yamada et al., 2009). Studies in Caco2 cells and Huh7 cells for the Sar55, a genotype $1 \mathrm{HEV}$ strain, showed that the intact PSAP motif spanning aa 96-99 in VP13 is required for virion release (Emerson et al., 2010; Nagashima et al., 2011b). For avian HEV, the PSAP motif in VP13 has also been found to play a role in virus release (Kenney et al., 2012). The PSAP motif in VP13 is required for the formation of membrane-associated HEV particles with the VP13 protein itself associated with lipids. This process is mediated by the cellular Tsg101 protein (Nagashima et al., 2011a,b). Replacement of the VP13 PSAP motif with heterologous late domain motifs (PPPY, YPDL, and PSAA) affects the virus release (Kenney et al., 2015). The specific interaction between VP13 and Tsg101 as well as involvement of endosomal sorting complex required for transport (ESCRT), which commonly participates in budding of many enveloped viruses, leads to the biogenesis of 
membrane-associated, "quasi-enveloped" HEV particles (Hurley, 2010; Feng et al., 2014; Nagashima et al., 2014; Yin et al., 2016). Therefore, VP13 is associated with virion during egress and anti-VP13 antibodies are able to capture HEV virions from the serum and cell culture supernatant, but not fecal samples from patients (Takahashi et al., 2008). A possible explanation is that viral particles could lose lipid-associated VP13 after passing through the gut (Takahashi et al., 2008). The role of VP13 in virus release may be one of its functions during HEV replication in vivo, indispensable for viral spread during infection.

On the other hand, as a small phosphorylated protein, VP13 can be phosphorylated at Ser71 by MAPK when expressed in COS1 and Huh7 cells (Zafrullah et al., 1997). A later study indicates that the Ser71 phosphorylation site is required for the interaction of the capsid protein and VP13 as VP13 can interact with the capsid protein in a yeast two-hybrid screen, especially for the non-glycosylated capsid protein (Tyagi et al., 2002). This finding also supports a role for VP13 in HEV structural assembly. However, a mutagenesis study shows that HEV lacking the phosphorylation site in VP13 is able to replicate its genome in cultured cells, and to infect rhesus monkeys similarly to wild type HEV in viremia and seroconversion (Graff et al., 2005). These data suggest that phosphorylation of VP13 is not necessary for genome replication or for the production of infectious virions. Moreover, in addition to phosphorylation and interaction with the capsid protein, VP13 can form a homodimer via the 43 aa domain located in the C-terminus (Tyagi et al., 2001b). On the other hand, VP13 has been reported to activate MAPK-JNK1/2 in hepatoma cells (Parvez and AlDosari, 2015).

Besides the functions mentioned above, VP13 also plays a role in the interferon induction and signaling. Data from our laboratory show that VP13 is able to enhance RIG-I activation, which leads to enhanced RIG-I signaling (Nan et al., 2014a). The VP13 extends RIG-I half-life and interacts with the $\mathrm{N}$-terminal portion of RIG-I to enhance its activation by polyI:C. Interestingly, there is a genotype difference in the enhancement of RIG-I: genotypes 1 and 3 VP13 but not genotypes 2 and 4 VP13 have the role, implicating that VP13 may relate to HEV virulence and pathogenesis. On the other hand, another study demonstrate that VP13 of a genotype $3 \mathrm{HEV}$ strain is able to interact with the STAT1 (signal transducer and activator of transcription) to inhibit interferon- $\alpha$ mediated signaling in A549 (human lung adenocarcinoma epithelial cell line; Dong et al., 2012).

In summary, as the product of the smallest ORF of HEV, VP13 has multiple functions and plays an indispensable role in infectivity in experimentally infected animal models. However, it is not required for HEV replication in cultured cells. Our current knowledge indicates that VP13 is a multifunctional protein in interacting with many cellular proteins, modulating host gene expression and involved in virion release.

\section{Novel ORF4 from Genotype 1 HEV}

Recently, a novel ORF4 (nt 2835-3308) was identified from genotype 1 HEV (Nair et al., 2016). Unlike other ORFs in
$\mathrm{HEV}$, translation of ORF4 is driven by an IRES-like sequence located in nt 2701-2787 of HEV genome (Nair et al., 2016). The ORF4 product interacts with multiple viral proteins to form a protein complex consisting of viral RdRp, helicase and $\mathrm{X}$, and the ORF4 product stimulated viral RdRp activity to promote viral replication. Expression of the ORF4 was verified in a cellfree system and antibodies against this protein were determined from HEV-infected patients (Nair et al., 2016). However, analysis of HEV sequences from other genotypes suggests ORF4 is not conserved across genotypes (Nair et al., 2016). Therefore, more investigation is needed to elucidate the exact function of ORF4.

\section{REPLICATION CYCLE OF HEV}

Due to the lack of an effective in vitro cell culture system for HEV, the replication cycle of HEV is largely unknown. The capsid protein is believed to bind to an unidentified cellular receptor to initiate viral entry. HEV-VLPs generated from recombinant ORF2 protein attach to cells via heparin sulfate proteoglycans (HSPGs; Kalia et al., 2009). Moreover, one study based on a viral overlay protein binding assay (VOPBA) suggests that a protein with molecular weight about $55 \mathrm{kDa}$ could be the candidate receptor for HEV entry; but mass spectrometry revealed that this virus binding band contained 31 different proteins (Zhang et al., 2011). Another study suggests that aa 458-607 located in the C-terminal region of the capsid protein ( $\mathrm{M}$ domain) may be the putative receptor binding site of HEV virions (He et al., 2008). Moreover, structure and sequence analyses suggest that the putative binding motif of the capsid protein is conserved among all four major mammalian HEV genotypes (Guu et al., 2009). Heat shock cognate protein 70 (HSC70), HSPGs and Grp78 are found to be involved in either cell surface binding with HEV capsids or intra-cellular transport in different models and are potential cellular receptors or essential factors for HEV proliferation (Kalia et al., 2009; Yu et al., 2011; Cao and Meng, 2012). However, further investigation is needed to confirm if these molecules truly act as receptors for HEV. After binding with its receptor, HEV particles are internalized via a dynamin-2, clathrin, and membrane cholesterol-dependent pathway (Kapur et al., 2012; Holla et al., 2015). In addition, a recent report suggests the quasienveloped HEV particles enter cells via a distinct pathway that involves in degradation of the lipid membrane in the lysosome (Yin et al., 2016).

After entry into permissive cells, the HEV capsid is uncoated by unknown mechanisms. In one study utilizing VLP from the truncated capsid protein HEV239, an HSP90-specific inhibitor (geldanamycin) blocks the intracellular transport of the HEV239 VLP without affecting its entry (Zheng et al., 2010). This suggests that HSP90 may play a role in the intracellular transport of HEV particles. After uncoating, the HEV ORF1 translation is followed. HEV genomic RNA replication relies on the replicase encoded by ORF1. Along with the generation of the sub-genomic RNA, translation of ORF2 and ORF3 occurs, followed by virion packing and egress. For the release of HEV particles, multivesicular body 
(MVB) pathway and ESCRT machinery in the cytoplasm are used (Nagashima et al., 2014).

\section{CELL CULTURE SYSTEMS AND PROPAGATION OF HEV}

Since the discovery of HEV, many efforts have been made to develop a rigorous in vitro cell culture system. However, the cell culture system of HEV is still limited and relatively ineffective, especially for genotype $1 \mathrm{HEV}$. An early study tried to use primary hepatocytes from macaques with serum-free medium for HEV propagation; however, HEV replication was limited and the detection of HEV in the medium relied on PCR amplification (Tam et al., 1996). A group from Japan reports that HEV isolate 87A is able to replicate in A549 cells; however, PCR was also used to detect viral RNA in the cell culture supernatant (Huang et al., 1995), instead of immunofluorescence assay to detect viral proteins. Another group also showed that the A549 cell line could be used effectively for passaging two Chinese HEV isolates (Wei et al., 2000).

On the other hand, as the commonly employed method for single-stranded, positive-sense RNA virus, transfection of capped RNA from an HEV cDNA infectious clone via in vitro transcription to PLC/PRF/5 (hepatocellular carcinoma) and Huh7 cells demonstrates limited replication of HEV (Emerson et al., 2004). Although cell lysates from the RNA transfected cells is infectious in rhesus monkeys, cell to cell spread of the virus in cultured cells is not observed (Emerson et al., 2004). S10-3 cell line, a subclone of Huh7 hepatoma cell line, has improved replication efficiency of HEV for the Sar55 strain (Graff et al., 2006; Shukla et al., 2011). But this assay still relies on transfection of the cells with full length HEV RNA. A recent report suggests that replication efficiency of genotype 1 HEV in human hepatoma cell lines (Huh7, Huh7.5, and HepG2/C3A) is affected by innate immune response (Devhare et al., 2016).

A Japanese group reports that a genotype 3 isolate from acute hepatitis patient propagates in PLC/PRF/5 and A549 cells (Tanaka et al., 2007; Okamoto, 2011). After A549 cells were seeded in a six-well plate and inoculated with HEV at $1.0 \times 10^{4}$ and $1.0 \times 10^{5}$ RNA copies per well, HEV RNA reached the highest titer of $10^{7}$ copies $/ \mathrm{ml}$ at 50 days post-inoculation. However, PLC/PRF/5 cells could only support efficient growth as A549 with a higher MOI $\left(1.0 \times 10^{5}\right.$ viral RNA copies per well). Moreover, in this HEV cell culture system, HEV infected cells need to be maintained at $35.5^{\circ} \mathrm{C}$ and cultured with a mixed cell culture medium (50\% Dulbecco's Modified Eagle Medium and $50 \%$ Medium 199) supplemented with $2 \%(\mathrm{v} / \mathrm{v})$ fetal bovine serum and $30 \mathrm{mM} \mathrm{MgCl}_{2}$. The same group also reports that a genotype $4 \mathrm{HEV}$ from a fulminant hepatitis patient can grow in $\mathrm{PLC} / \mathrm{PRF} / 5$ and A549 cells and reach a titer of $1.3 \times 10^{7}$ copies/ml within 10-20 days incubation period (Tanaka et al., 2009). Moreover, a human hepatoma-derived cell line HepaRG and a porcine embryonic stem cell-derived cell line PICM-19, which have morphological and functional properties similar to primary hepatocytes, were shown to support HEV replication
(Rogee et al., 2013). However, the HEV replication level in these two cell lines is very low and requires 1 month incubation (Rogee et al., 2013).

In HEV Kernow-C1 p6 cell culture system, the recombinant virus with human S17 gene insertion was presumed as a minor species in the host but was selectively adapted to cells after six passages (Shukla et al., 2011). Replication of Kernow-C1 p6 is 7.5-fold higher in HepG2/C3A human hepatoma cells than in Huh7.5, PLC/PRF/5, A549, Caco-2 or rhesus kidney cells in a 7-day incubation period, suggesting that HepG2/C3A cell line is the most permissive. Moreover, this HEV isolate is also able to infect a variety of non-primate cells, including cow, mouse, chicken, cat, dog, and rabbit cells, albeit with lower efficiency. Although it is still unclear how the insertion of S17 occurred in HEV infected patient, Okamoto's group demonstrated that two cell adapted HEV strains HEV JE03-1760F (genotype 3) and HEV JF5/15F (genotype 4) did not shown any recombination with cellular S17 gene after 53 and 33 generations of passages in PLC/PRF/5 and A549 cells, respectively (Okamoto, 2013), which suggested the recombination and insertion of S17 may occur in patients rather than in cultured cell. Besides human HEV isolates, animal HEV strains from domestic pigs, wild boars, rabbits, and rats can be propagated in human hepatoma cell lines as well (Jirintai et al., 2012, 2014; Takahashi et al., 2012). A recent report demonstrates that pluripotent stem cell derived hepatocytes support HEV replication in vitro (Helsen et al., 2016).

In summary, the current cell culture systems for HEV have limitations. So far, only one report shows limited replication of a genotype $1 \mathrm{HEV}$ strain from serum sample in cell culture without RNA transfection (Takahashi et al., 2010). On the other hand, although several groups have demonstrated that genotypes 3 or 4 HEV strains can be adapted to cultured cells and are able to reinfect new cells, a long incubation time is needed in comparison to other RNA viruses with good cell culture systems. Moreover, the cell culture adapted Kernow-C1 virus may have a different phenotype compared with its parental wild type virus as this cell culture adapted virus contains host gene sequence.

\section{EPIDEMIOLOGY OF HEV}

The HEV is primarily transmitted via fecal-oral route. The most common source of infection is contaminated drinking water in developing countries. For a long time, hepatitis E was thought to be a public health problem only for developing countries. However, hepatitis $\mathrm{E}$ is now frequently recognized in industrialized countries where it was not thought to be endemic previously (Kwo et al., 1997; Erker et al., 1999; Schlauder et al., 1999; Worm et al., 2000; Kabrane-Lazizi et al., 2001; Mizuo et al., 2002; Sadler et al., 2006).

World Health Organization estimates that there are 20 million HEV infections annually across the world. Among these cases, there are over 3 million symptomatic cases and 56,600 deaths (WHO, 2015). Hepatitis E is highly endemic in East and South Asia. Data indicates over 50\% of global hepatitis E deaths occur in this region. In East Asia, large outbreaks of hepatitis $\mathrm{E}$ have only been described in China. Hepatitis E accounts for $20-50 \%$ 
of acute hepatitis cases in this region. The seroprevalence of anti$\mathrm{HEV}$ antibodies in the region varies from 10 to $50 \%$, indicating that hepatitis $\mathrm{E}$ is hyperendemic in this region. In South Asia, outbreaks of hepatitis $\mathrm{E}$ have been reported in most countries in this region, but variable in scale (WHO, 2015). HEV accounts for $20-60 \%$ of sporadic acute hepatitis and fulminant liver failure in this region. In particular, the rates of fulminant liver failure are usually higher in pregnant patients. A recent paper reported that $\mathrm{HEV}$ infection causes $49 \%$ acute viral hepatitis and $75 \%$ fulminant hepatic failure in pregnant women in one area in India (Kumar et al., 2014). However, the seroprevalence rates of prior exposure to $\mathrm{HEV}$ are relatively low, ranging from 10 to $40 \%$ in most studies.

In the developed countries, such as North America, Western Europe and Japan, no outbreaks have been reported. These areas are considered as low or non-endemic for HEV. However, sporadic cases of hepatitis $\mathrm{E}$ have been reported. Transmission of HEV from animal reservoirs to humans is assumed to be the major cause of those sporadic cases. A series of cases of $\mathrm{HEV}$ infection in people who ate undercooked deer meat 67 weeks before the onset of disease have been reported (Tei et al., 2003; Yazaki et al., 2003; Li et al., 2005c). HEV RNA recovered from the leftover deer meat was found to be identical in sequence to the HEV RNA recovered from the patients (Takahashi et al., 2004). Consumption of shellfish is considered a risk factor in a documented case (Koizumi et al., 2004). Thus, foodborne infection may occur from the consumption of uncooked/undercooked products from infected animals. Moreover, blood transfusion and solid organ transplant mediated HEV transmission are reported (Pas et al., 2012; Wedemeyer et al., 2012; Sue et al., 2016). IgM and IgG against HEV are detected in recipients of blood transfusions (Wedemeyer et al., 2012).

Hepatitis E virus genotype 1 is responsible for most endemic and epidemic cases of hepatitis $\mathrm{E}$ in Asia, and genotype 2 is prevalent in Central America and Africa (Purcell and Emerson, 2008). There is no known animal reservoir for HEV genotypes 1 and 2 (Wedemeyer et al., 2012). Genotypes 3 and 4 are zoonotic and can cause HEV infections in the developed countries. For the detailed geographical distribution of hepatitis E virus genotypes, please refer to these reviews (Dalton et al., 2008; Kamar et al., 2012a).

\section{PATHOGENESIS, CLINICAL SIGNS, AND DIAGNOSIS OF HEV INFECTION}

Hepatitis E virus infection mainly causes acute hepatitis with a case fatality rate from 0.5 to $3 \%$ in young adults (Jameel, 1999). Remarkably, case fatality rate resulting from HEV-related fulminant liver failure can reach up to $30 \%$ in infected pregnant women in their third trimester of gestation (Jameel, 1999). Generally, HEV has an incubation period of 2-8 weeks (Purcell and Emerson, 2008). The initial symptoms of acute hepatitis E are unspecific and flu-like, such as myalgia, arthralgia, and weakness. After this short prodromal phase, a period of symptoms such as vomiting, itching, uncolored stools, darkened urine and jaundice could last for days to several weeks accompanied by increased levels of liver transaminases, bilirubin, alkaline phosphatase, and $\gamma$-glutamyltransferase (Hoofnagle et al., 2012; Wedemeyer et al., 2012). Current case reports indicate that most cases are selflimited and do not result in chronic hepatitis (Hoofnagle et al., 2012). An investigation on pregnancy outcomes in hepatitis $E$ shows higher HEV loads in pregnant women with acute viral hepatitis and fulminant hepatic failure, and higher levels of TNF- $\alpha$, IL- 6 , IFN- $\gamma$, and TGF- $\beta 1$ than non-pregnant women, which suggests that high cytokine levels are correlated with severe liver injury in HEV infection (Kumar et al., 2014). A recent study highlights the role of TLR3 and IFN- $\gamma$ in HEV pathogenesis. Patients with high levels of TLR3 and robust IFN- $\gamma$ response are observed in self-limiting acute viral hepatitis cases, and are able to limit the disease and recover uneventfully (Majumdar et al., 2015). However, patients with lower expression of TLR3 and IFN- $\gamma$ progress to acute liver failure (Majumdar et al., 2015).

HEV can cause chronic infection as well. Although chronic HEV infection was initially reported only in immunocompromised persons, such as organ transplant recipients, patients receiving cancer chemotherapy and HIV-infected persons (Hoofnagle et al., 2012), latest reports show that chronic $\mathrm{HEV}$ infection also occurs in an immunocompetent individual with systemic lupus erythematosus (SLE; Grewal et al., 2014). However, since this kind of cases are rare, data available so far are not sufficient to consider this patient as an immunocompetent individual (Kamar and Izopet, 2014). In organ transplant recipients, the chronic course leads to persistent increases in levels of alanine aminotransferase, significant histological activity and fibrosis in some cases (Wedemeyer et al., 2012). $\mathrm{HIV}$-infected individuals have higher positive rate of anti-HEV antibody than individuals without HIV infection (Wedemeyer et al., 2012).

Besides hepatitis, extrahepatic manifestations have been documented. Neurological disorders, such as polyradiculopathy, Guillain-Barré syndrome, bilateral brachial neuritis, encephalitis and proximal myopathy, and neuralgic amyotrophy are reported in patients with acute and chronic HEV infections (Kamar et al., 2011, 2014; van den Berg et al., 2014; van Eijk et al., 2014; Dalton et al., 2016; Drave et al., 2016). The kidney injury caused by HEV infection is reported and also documented in monkeys infected experimentally with HEV as well (Kamar et al., 2005, 2012b; Geng et al., 2016). Furthermore, a recent report provides evidence that extrahepatic replication of HEV in the placenta of infected mothers, which may be associated with fetal mortality (Bose et al., 2014). It also raises the concern for the vertical transmission of HEV to fetus and newborn by an infected mother (Krain et al., 2014).

A report suggests the association between the outcome of $\mathrm{HEV}$ infection in solid-organ transplant patients and the genetic heterogeneity of HEV quasispecies in ORF1 (Lhomme et al., 2014). Analysis of the viral genetic heterogeneity indicates that both nucleotide complexity and genetic distance of the ORF1 proline-rich domain in patients whose infection became chronic are higher than the patients who cleared the virus (Lhomme et al., 2014). 
Although diagnostic tests for HEV are commercially available, none of them have been formally approved in the United States by the Food and Drug Administration (FDA; Hoofnagle et al., 2012). Current tests mainly target anti-HEV antibodies, including IgG and IgM. However, several assays are based on antigens expressed by a single HEV genotype, especially genotype 3 , and might be limited for the detection of all HEV genotypes. Indeed, there are variations in sensitivity, specificity and agreement in the results of these assays, which may account for the discrepancies among positive rates of anti-HEV antibodies in various populations (Mast et al., 1998; Herremans et al., 2007; Drobeniuc et al., 2010). It is also notable that a recent study demonstrates the false positive result in HEV IgM test due to cross reaction with EBV and CMV, which heavily affects the accuracy of HEV serology testing (Hyams et al., 2014). Only 13.3\% of the total samples with the positive HEV IgM were PCR positive for HEV RNA. The cross reactivity of IgM against $\mathrm{HEV}, \mathrm{EBV}$, and CMV is very high. These data suggest that to confirm HEV infection in patients, clinical features, blood ALT level and PCR testing should be all included in addition to serological test alone.

On the other hand, although HEV RNA can also be detected in blood and stool for several weeks after acute HEV infection, in addition to a narrow detectable window of HEV viremia (Hyams et al., 2014), current HEV RNA tests are still experimental since they have not been standardized yet (Wedemeyer et al., 2012). Furthermore, diagnostic support for IgM and IgG anti-HEV detection in clinical samples using commercially available kits and PCR assay for detection of HEV RNA in serum and stool samples are also available from the Division of Viral Hepatitis in the Centers for Disease Control and Prevention (CDC, 2016).

\section{TREATMENT AND PREVENTION OF HEV INFECTION}

Hepatitis E virus infection mainly causes a self-limited disease and most infected individuals are able to clear it spontaneously. Although the case fatality rate in adults is $0.5-3 \%$, the rate can increase to $30 \%$ in pregnant women during their third trimester of gestation in South Asia (Jameel, 1999). Therefore, antiviral therapy is needed. Although no specific treatment has been approved for $\mathrm{HEV}$, off-label application of ribavirin as monotherapy for $\mathrm{HEV}$ has demonstrated promising results in both acute and chronic hepatitis E patients (Kamar et al., 2010; Mallet et al., 2010; Gerolami et al., 2011). In vitro assay showed that ribavirin could inhibit replication of genotypes 1-3 HEV through the depletion of intracellular GTP pools in HEV infected cells (Debing et al., 2014a). For immunosuppressed patients, a reduction of immunosuppression has shown efficacy in the treatment of chronic HEV infection (Wedemeyer et al., 2012). Moreover, application of pegylated interferon in combination with ribavirin has been reported as a treatment for chronic HEV infection but only shown moderately synergistic effect (Wedemeyer et al., 2012; Debing et al., 2014a). However, due to the evidence of embryolethality and teratogenicity revealed by animal study, ribavirin has been assigned to pregnancy category $\mathrm{X}$ by the FDA and contraindicated in women who are pregnant and in the male partners of women who are pregnant (Sayed et al., 2015). Moreover, ribavirin-induced G1634R mutation was reported and associated with treatment failure of ribavirin monotherapy in solid-organ transplant patients (Debing et al., 2014b; Lhomme et al., 2015; Todt et al., 2016). Therefore, viral specific treatment for HEV is needed.

Our laboratory has successfully tested application of peptideconjugated morpholino oligomers (PPMOs) as novel anti-HEV compounds (Nan et al., 2015). PPMOs are water soluble, nuclease-resistant single-stranded DNA analogs containing a backbone of morpholine rings and phosphorodiamidate linkages along with conjugation of arginine-rich cell penetrating peptide for facilitating cell delivery (Summerton, 1999; Abes et al., 2006). PPMOs bind to mRNA by Watson-Crick base pairing and interfere with translation through steric blockade of the AUGtranslation initiating region. Antisense morpholino oligomers are currently tested in clinical trials for treating Duchenne muscular dystrophy in humans and has been documented as effective against numerous types of viral infections in experimental animal models (Anthony et al., 2012; Mendell et al., 2013; Moulton, 2013). Importantly, upon systemic administration, PPMOs distribute to liver, remain pharmacologically viable, and are effective at reducing viral titers (Amantana et al., 2007; Burrer et al., 2007; Paessler et al., 2008). In our study, PPMO HP1 targeting $5^{\prime}$ UTR of HEV genotype 1 Sar55 strain demonstrates strong inhibition of HEV replication (Nan et al., 2015). Since the 5' UTR of HEV genome is highly conserved among different HEV genotypes infecting humans, the PPMO HP1 may be an HEVspecific inhibitor with antiviral activity across multiple HEV genotypes (Nan et al., 2015). These qualities, along with the in vitro efficacy against $\mathrm{HEV}$ (Nan et al., 2015), make PPMOs be appealing for consideration as a novel inhibitor of $\mathrm{HEV}$ infections.

Another nucleic-acid based strategy, siRNA, has also been reported to be effective in inhibiting HEV replication. An siRNA targeting HEV RdRp was reported to inhibit HEV replication in A549 cells and in piglets (Huang et al., 2009). In another report, siRNA targeting a $3^{\prime}$ cis-acting element and viral nucleotide sequences coding for helicase and RdRp are effective against HEV in HepG2 cells (Kumar et al., 2010). However, it is generally acknowledged that siRNA needs considerable improvements in their delivery to relevant targets in vivo before they can be considered for clinical applications involving systemic delivery against virus infections.

Current prevention for HEV relies on sanitary measures, such as providing clean water, and appropriately cooked food to avoid transmission from undercooked food (Kamar et al., 2012a). Since in vitro culturing of $\mathrm{HEV}$ is limited and ineffective, $\mathrm{HEV}$ vaccine development mainly focuses on the expression of the capsid protein as a subunit vaccine. The capsid protein shares over $85 \%$ identity among the four major HEV genotypes in mammalian hosts (Mori and Matsuura, 2011). The capsid protein from genotype $1 \mathrm{HEV}$ expressed by baculovirus or bacterial vectors has been tested in clinical trials. The first candidate was a $56 \mathrm{kDa}$ protein expressed in insect cells. In a phase 2 trial in Nepal, the vaccine is well-tolerated and highly immunogenic, with 95\% efficacy for protection against hepatitis E (Shrestha et al., 2007). 
The second vaccine, HEV239, encompasses aa 368-606 of ORF2 product, is a $26 \mathrm{kDa}$ truncated protein expressed in E. coli ( $\mathrm{Li}$ et al., 2005b). This vaccine is well-tolerated with an efficacy of $100 \%$ protection after three doses in a population tested in China, which included both men and women aged 16-65 years (Zhu et al., 2010). The HEV239 vaccine was approved and marketed in China in 2012. Whether it will be endorsed in other countries or how effective it is against all other genotypes of HEV infecting humans remains unknown. Moreover, a study shows that HEV239 vaccine could protect rabbits against homologous and heterologous HEV challenge (Liu et al., 2014; Zhang et al., 2015). A recent report demonstrates that a hybrid protein fusing protruding (P) domains from capsid proteins of both Norovirus (NoV) and HEV induces a higher antibody titer than either P domain alone (Wang et al., 2014a). Subunit vaccine candidates containing antigens of $\mathrm{HEV}$, rotavirus, and astrovirus are reported as well (Xia et al., 2016).

\section{CONCLUSION AND PERSPECTIVES}

More than 20 years have passed since the discovery and complete genome sequencing of HEV. Our understanding of HEV is still limited, though ongoing research continues to reveal more and more information about this virus. Currently, we know that HEV is not only a public health concern in developing countries as previously thought, but also a concern with a more complicated scenario in the developed countries. More and more animal reservoirs are revealed and we now understand that genotypes 3 and $4 \mathrm{HEV}$ are zoonotic and foodborne pathogens. However, the cross-species transmission and host tropism of different HEV genotypes are still elusive. Current data imply certain viral proteins such as ORF1 product plays a role in the host tropism of HEV. Further investigation is needed to elucidate the basic biology of HEV.

On the one hand, although approved in China, the HEV239 vaccine is still unavailable to most of the world, despite the fact that serum surveillance indicates a high prevalence rate of HEV throughout the world. Moreover, recent discoveries about the antigenicity variation between HEV genotypes and quasienveloped viral particles hidden from neutralizing antibody

\section{REFERENCES}

Abes, S., Moulton, H. M., Clair, P., Prevot, P., Youngblood, D. S., Wu, R. P., et al. (2006). Vectorization of morpholino oligomers by the (R-Ahx-R)4 peptide allows efficient splicing correction in the absence of endosomolytic agents. J. Control. Release 116, 304-313. doi: 10.1016/j.jconrel.2006. 09.011

Aggarwal, R., Shukla, R., Jameel, S., Agrawal, S., Puri, P., Gupta, V. K., et al. (2007). T-cell epitope mapping of ORF2 and ORF3 proteins of human hepatitis E virus. J. Viral Hepat. 14, 283-292. doi: 10.1111/j.1365-2893.2006.00796.x

Agrawal, S., Gupta, D., and Panda, S. K. (2001). The $3^{\prime}$ end of hepatitis E virus (HEV) genome binds specifically to the viral RNA-dependent RNA polymerase (RdRp). Virology 282, 87-101. doi: 10.1006/viro.2000.0819

Aguiar, R. C., Takeyama, K., He, C., Kreinbrink, K., and Shipp, M. A. (2005). $\mathrm{B}$-aggressive lymphoma family proteins have unique domains that modulate transcription and exhibit poly(ADP-ribose) polymerase activity. J. Biol. Chem. 280, 33756-33765. doi: 10.1074/jbc.M505408200 suggest new challenges and questions about the efficacy of the approved vaccine. Further investigation about the vaccine efficacy against multiple HEV genotypes or seeking for an improved vaccine is needed. In addition, virus specific treatment for $\mathrm{HEV}$ infection is not available yet. Although, the off-label using of pegylated IFNs and antiviral drugs for general purposes have demonstrated efficacy against HEV, safety is still a concern as no validation has yet been conducted for these treatments. Therefore, a HEV-specific treatment such as PPMOs is needed.

Due to the absence of a suitable animal model and a simple cell culture system, many details about this virus and its infection, such as its biology, pathogenesis, strain variances, genotype differences, molecular mechanisms and vaccine efficacy for cross protection are still incomplete. However, current information also indicates that it is possible to establish a useful cell culture system using certain HEV strains such as the cell culture-adapted Kernow-C1 strain. These recent advances will facilitate further studies, which hopefully will reveal more insights about the basic biology of HEV, such as proteolytic processing of ORF1 product, functions of the viral proteins, $\mathrm{HEV}$ pathogenesis, effective therapeutics and a better vaccine.

\section{AUTHOR CONTRIBUTION}

All authors listed, have made substantial, direct and intellectual contribution to the work, and approved it for publication.

\section{FUNDING}

This work was partly supported by a startup fund from Northwest $\mathrm{A} \& \mathrm{~F}$ University awarded to $\mathrm{YN}$ and a seed grant from the University of Maryland (College Park, MD, USA) to Y-JZ.

\section{ACKNOWLEDGMENT}

This review was modified from part of $\mathrm{Ph} . \mathrm{D}$ thesis by $\mathrm{YN}$ for partial fulfillment of the requirement for the degree of Doctor of Philosophy from University of Maryland.

Ahmad, I., Holla, R. P., and Jameel, S. (2011). Molecular virology of hepatitis E virus. Virus Res. 161, 47-58. doi: 10.1016/j.virusres.2011. 02.011

Allen, M. D., Buckle, A. M., Cordell, S. C., Lowe, J., and Bycroft, M. (2003). The crystal structure of AF1521 a protein from Archaeoglobus fulgidus with homology to the non-histone domain of macroH2A. J. Mol. Biol. 330, 503-511. doi: 10.1016/S0022-2836(03)00473-X

Amantana, A., Moulton, H. M., Cate, M. L., Reddy, M. T., Whitehead, T., Hassinger, J. N., et al. (2007). Pharmacokinetics, biodistribution, stability and toxicity of a cell-penetrating peptide-morpholino oligomer conjugate. Bioconjug. Chem. 18, 1325-1331. doi: 10.1021/bc070060v

Anang, S., Subramani, C., Nair, V. P., Kaul, S., Kaushik, N., Sharma, C., et al. (2016). Identification of critical residues in hepatitis $\mathrm{E}$ virus macro domain involved in its interaction with viral methyltransferase and ORF3 proteins. Sci. Rep. 6, 25133. doi: 10.1038/srep25133

Angelov, D., Molla, A., Perche, P. Y., Hans, F., Cote, J., Khochbin, S., et al. (2003). The histone variant macroH2A interferes with transcription factor 
binding and SWI/SNF nucleosome remodeling. Mol. Cell 11, 1033-1041. doi: 10.1016/S1097-2765(03)00100-X

Ansari, I. H., Nanda, S. K., Durgapal, H., Agrawal, S., Mohanty, S. K., Gupta, D., et al. (2000). Cloning, sequencing, and expression of the hepatitis $\mathrm{E}$ virus (HEV) nonstructural open reading frame 1 (ORF1). J. Med. Virol. 60, 275283. doi: 10.1002/(SICI)1096-9071(200003)60:3\%3C275::AID-JMV5\%3E3.0. $\mathrm{CO} ; 2-9$

Anthony, K., Feng, L., Arechavala-Gomeza, V., Guglieri, M., Straub, V., Bushby, K., et al. (2012). Exon skipping quantification by quantitative reverse-transcription polymerase chain reaction in Duchenne muscular dystrophy patients treated with the antisense oligomer eteplirsen. Hum. Gene. Ther. Methods 23, 336-345. doi: $10.1089 /$ hgtb.2012.117

Balayan, M. S., Andjaparidze, A. G., Savinskaya, S. S., Ketiladze, E. S., Braginsky, D. M., Savinov, A. P., et al. (1983). Evidence for a virus in non-A, nonB hepatitis transmitted via the fecal-oral route. Intervirology 20, 23-31. doi: $10.1159 / 000149370$

Batts, W., Yun, S., Hedrick, R., and Winton, J. (2011). A novel member of the family Hepeviridae from cutthroat trout (Oncorhynchus clarkii). Virus Res. 158, 116-123. doi: 10.1016/j.virusres.2011.03.019

Baumann, S., Grob, P., Stuart, F., Pertlik, D., Ackermann, M., and Suter, M. (1998). Indirect immobilization of recombinant proteins to a solid phase using the albumin binding domain of streptococcal protein $G$ and immobilized albumin. J. Immunol. Methods 221, 95-106. doi: 10.1016/S0022-1759(98) 00168-9

Behloul, N., Wen, J., Dai, X., Dong, C., and Meng, J. (2015). Antigenic composition and immunoreactivity differences between HEV recombinant capsid proteins generated from different genotypes. Infect. Genet. Evol. 34, 211-220. doi: 10.1016/j.meegid.2015.06.026

Berke, T., and Matson, D. O. (2000). Reclassification of the Caliciviridae into distinct genera and exclusion of hepatitis $\mathrm{E}$ virus from the family on the basis of comparative phylogenetic analysis. Arch. Virol. 145, 1421-1436. doi: $10.1007 / \mathrm{s} 007050070099$

Bose, P. D., Das, B. C., Hazam, R. K., Kumar, A., Medhi, S., and Kar, P. (2014). Evidence of extrahepatic replication of hepatitis $\mathrm{E}$ virus in human placenta. J. Gen. Virol. 95, 1266-1271. doi: 10.1099/vir.0.063602-0

Burrer, R., Neuman, B. W., Ting, J. P., Stein, D. A., Moulton, H. M., Iversen, P. L., et al. (2007). Antiviral effects of antisense morpholino oligomers in murine coronavirus infection models. J. Virol. 81, 5637-5648. doi: 10.1128/JVI. 02360-06

Cao, D., Huang, Y. W., and Meng, X. J. (2010). The nucleotides on the stemloop RNA structure in the junction region of the hepatitis $\mathrm{E}$ virus genome are critical for virus replication. J. Virol. 84, 13040-13044. doi: 10.1128/JVI. 01475-10

Cao, D., and Meng, X. J. (2012). Molecular biology and replication of hepatitis E virus. Emerg. Microbes Infect. 1, e17. doi: 10.1038/emi.2012.7

CDC (2016). HEV Laboratory Testing Requests [Online]. Available: http://www.cdc. gov/hepatitis/hev/labtestingrequests.htm

Chandra, V., Holla, P., Ghosh, D., Chakrabarti, D., Padigaru, M., and Jameel, S. (2011). The hepatitis E virus ORF3 protein regulates the expression of liverspecific genes by modulating localization of hepatocyte nuclear factor 4. PLoS ONE 6:e22412. doi: 10.1371/journal.pone.0022412

Chandra, V., Kalia, M., Hajela, K., and Jameel, S. (2010). The ORF3 protein of hepatitis $\mathrm{E}$ virus delays degradation of activated growth factor receptors by interacting with CIN85 and blocking formation of the Cbl-CIN85 complex. J. Virol. 84, 3857-3867. doi: 10.1128/JVI.01994-09

Chandra, V., Kar-Roy, A., Kumari, S., Mayor, S., and Jameel, S. (2008). The hepatitis E virus ORF3 protein modulates epidermal growth factor receptor trafficking, STAT3 translocation, and the acute-phase response. J. Virol. 82, 7100-7110. doi: 10.1128/JVI.00403-08

Chatterjee, S. N., Devhare, P. B., Pingle, S. Y., Paingankar, M. S., Arankalle, V. A., and Lole, K. S. (2016). HEV-1 harbouring HEV-4 nonstructural protein (ORF1) replicates in transfected porcine kidney cells. J. Gen. Virol. doi: 10.1099/jgv.0.000478 [Epub ahead of print].

Chen, L., Hu, L., Chan, T. H., Tsao, G. S., Xie, D., Huo, K. K., et al. (2009). Chromodomain helicase/adenosine triphosphatase DNA binding protein 1-like (CHD1l) gene suppresses the nucleus-to-mitochondria translocation of nur77 to sustain hepatocellular carcinoma cell survival. Hepatology 50, 122-129. doi: 10.1002/hep.22933
Christensen, P. B., Engle, R. E., Hjort, C., Homburg, K. M., Vach, W., Georgsen, J., et al. (2008). Time trend of the prevalence of hepatitis $\mathrm{E}$ antibodies among farmers and blood donors: a potential zoonosis in Denmark. Clin. Infect. Dis. 47, 1026-1031. doi: 10.1086/591970

Cossaboom, C. M., Cordoba, L., Cao, D., Ni, Y. Y., and Meng, X. J. (2012). Complete genome sequence of hepatitis $\mathrm{E}$ virus from rabbits in the United States. J. Virol. 86, 13124-13125. doi: 10.1128/JVI.02414-12

Costanzi, C., and Pehrson, J. R. (1998). Histone macroH2A1 is concentrated in the inactive X chromosome of female mammals. Nature 393, 599-601. doi: $10.1038 / 31275$

Dalton, H. R., Bendall, R., Ijaz, S., and Banks, M. (2008). Hepatitis E: an emerging infection in developed countries. Lancet Infect. Dis. 8, 698-709. doi: 10.1016/S1473-3099(08)70255-X

Dalton, H. R., Kamar, N., Van Eijk, J. J., Mclean, B. N., Cintas, P., Bendall, R. P., et al. (2016). Hepatitis E virus and neurological injury. Nat. Rev. Neurol. 12, 77-85. doi: 10.1038/nrneurol.2015.234

Debing, Y., Emerson, S. U., Wang, Y., Pan, Q., Balzarini, J., Dallmeier, K., et al. (2014a). Ribavirin inhibits in vitro hepatitis E virus replication through depletion of cellular GTP pools and is moderately synergistic with alpha interferon. Antimicrob. Agents Chemother. 58, 267-273. doi: 10.1128/AAC.01795-13

Debing, Y., Gisa, A., Dallmeier, K., Pischke, S., Bremer, B., Manns, M., et al. (2014b). A mutation in the hepatitis E virus RNA polymerase promotes its replication and associates with ribavirin treatment failure in organ transplant recipients. Gastroenterology 147, 1008-1011 e7; quiz e15-6. doi: 10.1053/j.gastro.2014.08.040

Dement'eva, E. V., Semiletov Iu, A., Iashina, T. L., and Shibnev, V. A. (1997). [Analysis of the organization of immunodominant epitopes of hepatitis virus E orf2 and orf3 proteins using synthetic peptides]. Vopr. Virusol. 42, 102-105.

Devhare, P. B., Desai, S., and Lole, K. S. (2016). Innate immune responses in human hepatocyte-derived cell lines alter genotype 1 hepatitis E virus replication efficiencies. Sci. Rep. 6:26827. doi: 10.1038/srep26827

Dong, C., Zafrullah, M., Mixson-Hayden, T., Dai, X., Liang, J., Meng, J., et al. (2012). Suppression of interferon-alpha signaling by hepatitis E virus. Hepatology 55, 1324-1332. doi: 10.1002/hep.25530

Dosztanyi, Z., Chen, J., Dunker, A. K., Simon, I., and Tompa, P. (2006). Disorder and sequence repeats in hub proteins and their implications for network evolution. J. Proteome Res. 5, 2985-2995. doi: 10.1021/pr060171o

Drave, S. A., Debing, Y., Walter, S., Todt, D., Engelmann, M., Friesland, M., et al. (2016). Extra-hepatic replication and infection of hepatitis $\mathrm{E}$ virus in neuronal-derived cells. J. Viral. Hepat. 23:512-521. doi: 10.1111/jvh.12515

Drexler, J. F., Seelen, A., Corman, V. M., Fumie Tateno, A., Cottontail, V., Melim Zerbinati, R., et al. (2012). Bats worldwide carry hepatitis E virus-related viruses that form a putative novel genus within the family Hepeviridae. J. Virol. 86, 9134-9147. doi: 10.1128/JVI.00800-12

Drobeniuc, J., Meng, J., Reuter, G., Greene-Montfort, T., Khudyakova, N., Dimitrova, Z., et al. (2010). Serologic assays specific to immunoglobulin M antibodies against hepatitis $\mathrm{E}$ virus: pangenotypic evaluation of performances. Clin. Infect. Dis. 51, e24-e27. doi: 10.1086/654801

Dunker, A. K., Oldfield, C. J., Meng, J., Romero, P., Yang, J. Y., Chen, J. W., et al. (2008). The unfoldomics decade: an update on intrinsically disordered proteins. BMC Genomics 9(Suppl. 2), S1. doi: 10.1186/1471-2164-9-S2-S1

Egloff, M. P., Malet, H., Putics, A., Heinonen, M., Dutartre, H., Frangeul, A., et al. (2006). Structural and functional basis for ADP-ribose and poly(ADPribose) binding by viral macro domains. J. Virol. 80, 8493-8502. doi: 10.1128/JVI.00713-06

Emerson, S. U., Nguyen, H., Graff, J., Stephany, D. A., Brockington, A., and Purcell, R. H. (2004). In vitro replication of hepatitis $E$ virus (HEV) genomes and of an HEV replicon expressing green fluorescent protein. J. Virol. 78, 4838-4846. doi: 10.1128/JVI.78.9.4838-4846.2004

Emerson, S. U., Nguyen, H., Torian, U., and Purcell, R. H. (2006). ORF3 protein of hepatitis $\mathrm{E}$ virus is not required for replication, virion assembly, or infection of hepatoma cells in vitro. J. Virol. 80, 10457-10464. doi: 10.1128/JVI. 00892-06

Emerson, S. U., Nguyen, H. T., Torian, U., Burke, D., Engle, R., and Purcell, R. H. (2010). Release of genotype 1 hepatitis E virus from cultured hepatoma and polarized intestinal cells depends on open reading frame 3 protein and requires an intact PXXP motif. J. Virol. 84, 9059-9069. doi: 10.1128/JVI.00593-10 
Emerson, S. U., and Purcell, R. H. (2003). Hepatitis E virus. Rev. Med. Virol. 13, 145-154. doi: 10.1002/rmv.384

Emerson, S. U., Zhang, M., Meng, X. J., Nguyen, H., St Claire, M., Govindarajan, S., et al. (2001). Recombinant hepatitis $\mathrm{E}$ virus genomes infectious for primates: importance of capping and discovery of a cis-reactive element. Proc. Natl. Acad. Sci. U.S.A. 98, 15270-15275. doi: 10.1073/pnas.251555098

Erker, J. C., Desai, S. M., Schlauder, G. G., Dawson, G. J., and Mushahwar, I. K. (1999). A hepatitis E virus variant from the United States: molecular characterization and transmission in cynomolgus macaques. J. Gen. Virol. 80 (Pt. 3), 681-690. doi: 10.1099/0022-1317-80-3-681

Feng, Z., Hirai-Yuki, A., Mcknight, K. L., and Lemon, S. M. (2014). Naked viruses that aren't always naked: quasi-enveloped agents of acute hepatitis. Annu. Rev. Virol. 1, 539-560. doi: 10.1146/annurev-virology-031413-085359

Geng, Y., Zhao, C., Huang, W., Harrison, T. J., Zhang, H., Geng, K., et al. (2016). Detection and assessment of infectivity of hepatitis E virus in urine. J. Hepatol. 64, 37-43. doi: 10.1016/j.jhep.2015.08.034

Geng, Y., Zhao, C., Song, A., Wang, J., Zhang, X., Harrison, T. J., et al. (2011). The serological prevalence and genetic diversity of hepatitis $\mathrm{E}$ virus in farmed rabbits in China. Infect. Genet. Evol. 11, 476-482. doi: 10.1016/j.meegid.2010.12.012

Gerolami, R., Borentain, P., Raissouni, F., Motte, A., Solas, C., and Colson, P. (2011). Treatment of severe acute hepatitis E by ribavirin. J. Clin. Virol. 52, 60-62. doi: 10.1016/j.jcv.2011.06.004

Gorbalenya, A. E., Koonin, E. V., and Lai, M. M. (1991). Putative papain-related thiol proteases of positive-strand RNA viruses. Identification of rubi- and aphthovirus proteases and delineation of a novel conserved domain associated with proteases of rubi-, alpha- and coronaviruses. FEBS Lett. 288, 201-205. doi: 10.1016/0014-5793(91)81034-6

Graff, J., Nguyen, H., Yu, C., Elkins, W. R., St Claire, M., Purcell, R. H., et al. (2005). The open reading frame 3 gene of hepatitis $\mathrm{E}$ virus contains a cis-reactive element and encodes a protein required for infection of macaques. J. Virol. 79, 6680-6689. doi: 10.1128/JVI.79.11.6680-6689.2005

Graff, J., Torian, U., Nguyen, H., and Emerson, S. U. (2006). A bicistronic subgenomic mRNA encodes both the ORF2 and ORF3 proteins of hepatitis E virus. J. Virol. 80, 5919-5926. doi: 10.1128/JVI.00046-06

Graff, J., Zhou, Y. H., Torian, U., Nguyen, H., St Claire, M., Yu, C., et al. (2008). Mutations within potential glycosylation sites in the capsid protein of hepatitis $\mathrm{E}$ virus prevent the formation of infectious virus particles. J. Virol. 82, 1185-1194. doi: 10.1128/JVI.01219-07

Grewal, P., Kamili, S., and Motamed, D. (2014). Chronic hepatitis E in an immunocompetent patient: a case report. Hepatology 59, 347-348. doi: 10.1002/hep.26636

Gu, Y., Tang, X., Zhang, X., Song, C., Zheng, M., Wang, K., et al. (2015). Structural basis for the neutralization of hepatitis $\mathrm{E}$ virus by a cross-genotype antibody. Cell Res. 25, 604-620. doi: 10.1038/cr.2015.34

Guu, T. S., Liu, Z., Ye, Q., Mata, D. A., Li, K., Yin, C., et al. (2009). Structure of the hepatitis E virus-like particle suggests mechanisms for virus assembly and receptor binding. Proc. Natl. Acad. Sci. U.S.A. 106, 12992-12997. doi: 10.1073/pnas.0904848106

Haqshenas, G., Huang, F. F., Fenaux, M., Guenette, D. K., Pierson, F. W., Larsen, C. T., et al. (2002). The putative capsid protein of the newly identified avian hepatitis $\mathrm{E}$ virus shares antigenic epitopes with that of swine and human hepatitis E viruses and chicken big liver and spleen disease virus. J. Gen. Virol. 83, 2201-2209. doi: 10.1099/0022-1317-83-9-2201

Haqshenas, G., Shivaprasad, H. L., Woolcock, P. R., Read, D. H., and Meng, X. J. (2001). Genetic identification and characterization of a novel virus related to human hepatitis E virus from chickens with hepatitis-splenomegaly syndrome in the United States. J. Gen. Virol. 82, 2449-2462. doi: 10.1099/0022-1317-82$10-2449$

He, S., Miao, J., Zheng, Z., Wu, T., Xie, M., Tang, M., et al. (2008). Putative receptor-binding sites of hepatitis E virus. J. Gen. Virol. 89, 245-249. doi: 10.1099/vir.0.83308-0

Helsen, N., Debing, Y., Paeshuyse, J., Dallmeier, K., Boon, R., Coll, M., et al. (2016). Stem cell-derived hepatocytes: a novel model for hepatitis E virus replication. J. Hepatol. 64, 565-573. doi: 10.1016/j.jhep.2015.11.013

Herremans, M., Bakker, J., Duizer, E., Vennema, H., and Koopmans, M. P. (2007). Use of serological assays for diagnosis of hepatitis E virus genotype 1 and 3 infections in a setting of low endemicity. Clin. Vaccine Immunol. 14, 562-568. doi: 10.1128/CVI.00231-06
Holla, P., Ahmad, I., Ahmed, Z., and Jameel, S. (2015). Hepatitis E virus enters liver cells through a dynamin-2, clathrin and membrane cholesterol-dependent pathway. Traffic 16, 398-416. doi: 10.1111/tra.12260

Holla, R. P., Ahmad, I., Ahmad, Z., and Jameel, S. (2013). Molecular virology of hepatitis E virus. Semin. Liver Dis. 33, 3-14. doi: 10.1055/s-0033-1338110

Hoofnagle, J. H., Nelson, K. E., and Purcell, R. H. (2012). Hepatitis E. N. Engl. J. Med. 367, 1237-1244. doi: 10.1056/NEJMra1204512

Huang, F., Hua, X., Yang, S., Yuan, C., and Zhang, W. (2009). Effective inhibition of hepatitis E virus replication in A549 cells and piglets by RNA interference (RNAi) targeting RNA-dependent RNA polymerase. Antiviral Res. 83, 274-281. doi: 10.1016/j.antiviral.2009.06.008

Huang, F. F., Sun, Z. F., Emerson, S. U., Purcell, R. H., Shivaprasad, H. L., Pierson, F. W., et al. (2004). Determination and analysis of the complete genomic sequence of avian hepatitis E virus (avian HEV) and attempts to infect rhesus monkeys with avian HEV. J. Gen. Virol. 85, 1609-1618. doi: 10.1099/vir.0.79841-0

Huang, R., Nakazono, N., Ishii, K., Li, D., Kawamata, O., Kawaguchi, R., et al. (1995). Hepatitis E virus (87A strain) propagated in A549 cells. J. Med. Virol. 47, 299-302. doi: 10.1002/jmv.1890470402

Huang, Y. W., Opriessnig, T., Halbur, P. G., and Meng, X. J. (2007). Initiation at the third in-frame AUG codon of open reading frame 3 of the hepatitis E virus is essential for viral infectivity in vivo. J. Virol. 81, 3018-3026. doi: 10.1128/JVI.02259-06

Hurley, J. H. (2010). The ESCRT complexes. Crit. Rev. Biochem. Mol. Biol. 45, 463-487. doi: 10.3109/10409238.2010.502516

Hyams, C., Mabayoje, D. A., Copping, R., Maranao, D., Patel, M., Labbett, W., et al. (2014). Serological cross reactivity to CMV and EBV causes problems in the diagnosis of acute hepatitis E virus infection. J. Med. Virol. 86, 478-483. doi: $10.1002 /$ jmv. 23827

Ichiyama, K., Yamada, K., Tanaka, T., Nagashima, S., Jirintai, Takahashi, M., and Okamoto, H. (2009). Determination of the $5^{\prime}$-terminal sequence of subgenomic RNA of hepatitis E virus strains in cultured cells. Arch. Virol. 154, 1945-1951. doi: 10.1007/s00705-009-0538-y

Jameel, S. (1999). Molecular biology and pathogenesis of hepatitis E virus. Expert Rev. Mol. Med. 1999, 1-16. doi: 10.1017/s1462399499001271

Jameel, S., Zafrullah, M., Ozdener, M. H., and Panda, S. K. (1996). Expression in animal cells and characterization of the hepatitis $\mathrm{E}$ virus structural proteins. J. Virol. 70, 207-216.

Jirintai, S., Jinshan, Tanggis, Manglai, D., Mulyanto, Takahashi, M., et al. (2012). Molecular analysis of hepatitis E virus from farm rabbits in Inner Mongolia, China and its successful propagation in A549 and PLC/PRF/5 cells. Virus Res. 170, 126-137. doi: 10.1016/j.virusres.2012.09.015

Jirintai, S., Tanggis, Mulyanto, Suparyatmo, J. B., Takahashi, M., Kobayashi, T., et al. (2014). Rat hepatitis E virus derived from wild rats (Rattus rattus) propagates efficiently in human hepatoma cell lines. Virus Res. 185, 92-102. doi: 10.1016/j.virusres.2014.03.002

John, L., Thomas, S., Herchenroder, O., Putzer, B. M., and Schaefer, S. (2011). Hepatitis E virus ORF2 protein activates the pro-apoptotic gene CHOP and anti-apoptotic heat shock proteins. PLoS ONE 6:e25378. doi: 10.1371/journal.pone.0025378

Johne, R., Plenge-Bonig, A., Hess, M., Ulrich, R. G., Reetz, J., and Schielke, A. (2010). Detection of a novel hepatitis E-like virus in faeces of wild rats using a nested broad-spectrum RT-PCR. J. Gen. Virol. 91, 750-758. doi: 10.1099/vir.0.016584-0

Kabrane-Lazizi, Y., Zhang, M., Purcell, R. H., Miller, K. D., Davey, R. T., and Emerson, S. U. (2001). Acute hepatitis caused by a novel strain of hepatitis E virus most closely related to United States strains. J. Gen. Virol. 82, 1687-1693. doi: 10.1099/0022-1317-82-7-1687

Kadare, G., and Haenni, A. L. (1997). Virus-encoded RNA helicases. J. Virol. 71, 2583-2590.

Kalia, M., Chandra, V., Rahman, S. A., Sehgal, D., and Jameel, S. (2009). Heparan sulfate proteoglycans are required for cellular binding of the hepatitis E virus ORF2 capsid protein and for viral infection. J. Virol. 83, 12714-12724. doi: 10.1128/JVI.00717-09

Kamar, N., Abravanel, F., Lhomme, S., Rostaing, L., and Izopet, J. (2014). Hepatitis E virus: chronic infection, extra-hepatic manifestations, and treatment. Clin. Res. Hepatol. Gastroenterol. 39, 20-27. doi: 10.1016/j.clinre.2014. 07.005 
Kamar, N., Bendall, R., Legrand-Abravanel, F., Xia, N. S., Ijaz, S., Izopet, J., et al. (2012a). Hepatitis E. Lancet 379, 2477-2488. doi: 10.1016/S01406736(11)61849-7

Kamar, N., Bendall, R. P., Peron, J. M., Cintas, P., Prudhomme, L., Mansuy, J. M., et al. (2011). Hepatitis E virus and neurologic disorders. Emerg. Infect. Dis. 17, 173-179. doi: 10.3201/eid1702.100856

Kamar, N., and Izopet, J. (2014). Does chronic hepatitis E virus infection exist in immunocompetent patients? Hepatology 60:427. doi: 10.1002/hep.26927

Kamar, N., Mansuy, J. M., Esposito, L., Legrand-Abravanel, F., Peron, J. M., Durand, D., et al. (2005). Acute hepatitis and renal function impairment related to infection by hepatitis E virus in a renal allograft recipient. Am. J. Kidney Dis. 45, 193-196. doi: 10.1053/j.ajkd.2004.09.006

Kamar, N., Rostaing, L., Abravanel, F., Garrouste, C., Lhomme, S., Esposito, L., et al. (2010). Ribavirin therapy inhibits viral replication on patients with chronic hepatitis e virus infection. Gastroenterology 139, 1612-1618. doi: 10.1053/j.gastro.2010.08.002

Kamar, N., Weclawiak, H., Guilbeau-Frugier, C., Legrand-Abravanel, F., Cointault, O., Ribes, D., et al. (2012b). Hepatitis E virus and the kidney in solid-organ transplant patients. Transplantation 93, 617-623. doi: 10.1097/TP.0b013e318245f14c

Kannan, H., Fan, S., Patel, D., Bossis, I., and Zhang, Y. J. (2009). The hepatitis E virus open reading frame 3 product interacts with microtubules and interferes with their dynamics. J. Virol. 83, 6375-6382. doi: 10.1128/JVI.02571-08

Kapur, N., Thakral, D., Durgapal, H., and Panda, S. K. (2012). Hepatitis E virus enters liver cells through receptor-dependent clathrin-mediated endocytosis. J. Viral. Hepat. 19, 436-448. doi: 10.1111/j.1365-2893.2011.01559.x

Karpe, Y. A., and Lole, K. S. (2010a). NTPase and $5^{\prime}$ to $3^{\prime}$ RNA duplex-unwinding activities of the hepatitis E virus helicase domain. J. Virol. 84, 3595-3602. doi: 10.1128/JVI.02130-09

Karpe, Y. A., and Lole, K. S. (2010b). RNA 5'-triphosphatase activity of the hepatitis E virus helicase domain. J. Virol. 84, 9637-9641. doi: 10.1128/JVI.00492-10

Karpe, Y. A., and Lole, K. S. (2011). Deubiquitination activity associated with hepatitis E virus putative papain-like cysteine protease. J. Gen. Virol. 92, 2088-2092. doi: 10.1099/vir.0.033738-0

Kar-Roy, A., Korkaya, H., Oberoi, R., Lal, S. K., and Jameel, S. (2004). The hepatitis $\mathrm{E}$ virus open reading frame 3 protein activates ERK through binding and inhibition of the MAPK phosphatase. J. Biol. Chem. 279, 28345-28357. doi: 10.1074/jbc.M400457200

Kenney, S. P., and Meng, X. J. (2015a). Identification and fine mapping of nuclear and nucleolar localization signals within the human ribosomal protein S17. PLoS ONE 10, e0124396. doi: 10.1371/journal.pone.0124396

Kenney, S. P., and Meng, X. J. (2015b). The lysine residues within the human ribosomal protein S17 sequence naturally inserted into the viral nonstructural protein of a unique strain of hepatitis E virus are important for enhanced virus replication. J. Virol. 89, 3793-3803. doi: 10.1128/JVI.03582-14

Kenney, S. P., Pudupakam, R. S., Huang, Y. W., Pierson, F. W., Leroith, T., and Meng, X. J. (2012). The PSAP motif within the ORF3 protein of an avian strain of the hepatitis $\mathrm{E}$ virus is not critical for viral infectivity in vivo but plays a role in virus release. J. Virol. 86, 5637-5646. doi: 10.1128/JVI.06711-11

Kenney, S. P., Wentworth, J. L., Heffron, C. L., and Meng, X. J. (2015). Replacement of the hepatitis E virus ORF3 protein PxxP motif with heterologous late domain motifs affects virus release via interaction with TSG101. Virology 486, 198-208. doi: 10.1016/j.virol.2015.09.012

Koizumi, Y., Isoda, N., Sato, Y., Iwaki, T., Ono, K., Ido, K., et al. (2004). Infection of a Japanese patient by genotype 4 hepatitis e virus while traveling in Vietnam. J. Clin. Microbiol. 42, 3883-3885. doi: 10.1128/JCM.42.8.3883-3885.2004

Koonin, E. V. (1991). The phylogeny of RNA-dependent RNA polymerases of positive-strand RNA viruses. J. Gen. Virol. 72 (Pt. 9), 2197-2206. doi: 10.1099/0022-1317-72-9-2197

Koonin, E. V., and Dolja, V. V. (1993). Evolution and taxonomy of positive-strand RNA viruses: implications of comparative analysis of amino acid sequences. Crit. Rev. Biochem. Mol. Biol. 28, 375-430. doi: 10.3109/104092393090 78440

Koonin, E. V., Gorbalenya, A. E., Purdy, M. A., Rozanov, M. N., Reyes, G. R., and Bradley, D. W. (1992). Computer-assisted assignment of functional domains in the nonstructural polyprotein of hepatitis E virus: delineation of an additional group of positive-strand RNA plant and animal viruses. Proc. Natl. Acad. Sci. U.S.A. 89, 8259-8263. doi: 10.1073/pnas.89.17.8259
Korkaya, H., Jameel, S., Gupta, D., Tyagi, S., Kumar, R., Zafrullah, M., et al. (2001). The ORF3 protein of hepatitis E virus binds to Src homology 3 domains and activates MAPK. J. Biol. Chem. 276, 42389-42400. doi: 10.1074/jbc.M1015 46200

Krain, L. J., Atwell, J. E., Nelson, K. E., and Labrique, A. B. (2014). Fetal and neonatal health consequences of vertically transmitted hepatitis $\mathrm{E}$ virus infection. Am. J. Trop. Med. Hyg. 90, 365-370. doi: 10.4269/ajtmh.13-0265

Krog, J. S., Breum, S. O., Jensen, T. H., and Larsen, L. E. (2013). Hepatitis E virus variant in farmed mink, Denmark. Emerg. Infect. Dis. 19, 2028-2030. doi: 10.3201/eid1912.130614

Kumar, A., Devi, S. G., Kar, P., Agarwal, S., Husain, S. A., Gupta, R. K., et al. (2014). Association of cytokines in hepatitis E with pregnancy outcome. Cytokine 65, 95-104. doi: 10.1016/j.cyto.2013.09.022

Kumar, A., Panda, S. K., Durgapal, H., Acharya, S. K., Rehman, S., and Kar, U. K. (2010). Inhibition of Hepatitis E virus replication using short hairpin RNA (shRNA). Antiviral Res. 85, 541-550. doi: 10.1016/j.antiviral.2010. 01.005

Kwo, P. Y., Schlauder, G. G., Carpenter, H. A., Murphy, P. J., Rosenblatt, J. E., Dawson, G. J., et al. (1997). Acute hepatitis $\mathrm{E}$ by a new isolate acquired in the United States. Mayo Clin. Proc. 72, 1133-1136. doi: 10.4065/72.12.1133

Lapa, D., Capobianchi, M. R., and Garbuglia, A. R. (2015). Epidemiology of Hepatitis E virus in European Countries. Int. J. Mol. Sci. 16, 25711-25743. doi: 10.3390/ijms161025711

Lhomme, S., Garrouste, C., Kamar, N., Saune, K., Abravanel, F., Mansuy, J. M., et al. (2014). Influence of polyproline region and macro domain genetic heterogeneity on HEV persistence in immunocompromised patients. J. Infect. Dis. 209, 300-303. doi: 10.1093/infdis/jit438

Lhomme, S., Kamar, N., Nicot, F., Ducos, J., Bismuth, M., Garrigue, V., et al. (2015). Mutation in the Hepatitis E virus polymerase and outcome of ribavirin therapy. Antimicrob. Agents Chemother. 60, 1608-1614. doi: 10.1128/AAC.02496-15

Li, C., Debing, Y., Jankevicius, G., Neyts, J., Ahel, I., Coutard, B., et al. (2016). Viral macro domains reverse protein ADP-ribosylation. J. Virol. doi: 10.1128/JVI.00705-16 [Epub ahead of print].

Li, H., Zheng, Z., Zhou, P., Zhang, B., Shi, Z., Hu, Q., et al. (2010). The cysteine protease domain of porcine reproductive and respiratory syndrome virus nonstructural protein 2 antagonizes interferon regulatory factor 3 activation. J. Gen. Virol. 91, 2947-2958. doi: 10.1099/vir.0.025205-0

Li, S. W., Zhang, J., He, Z. Q., Gu, Y., Liu, R. S., Lin, J., et al. (2005a). Mutational analysis of essential interactions involved in the assembly of hepatitis E virus capsid. J. Biol. Chem. 280, 3400-3406. doi: 10.1074/jbc.M4103 61200

Li, S. W., Zhang, J., Li, Y. M., Ou, S. H., Huang, G. Y., He, Z. Q., et al. (2005b). A bacterially expressed particulate hepatitis E vaccine: antigenicity, immunogenicity and protectivity on primates. Vaccine 23, 2893-2901. doi: 10.1016/j.vaccine.2004.11.064

Li, T. C., Chijiwa, K., Sera, N., Ishibashi, T., Etoh, Y., Shinohara, Y., et al. (2005c). Hepatitis E virus transmission from wild boar meat. Emerg. Infect. Dis. 11, 1958-1960. doi: 10.3201/eid1112.051041

Li, T. C., Takeda, N., Miyamura, T., Matsuura, Y., Wang, J. C., Engvall, H., et al. (2005d). Essential elements of the capsid protein for self-assembly into empty virus-like particles of hepatitis E virus. J. Virol. 79, 12999-13006. doi: 10.1128/JVI.79.20.12999-13006.2005

Li, T. C., Yamakawa, Y., Suzuki, K., Tatsumi, M., Razak, M. A., Uchida, T., et al. (1997). Expression and self-assembly of empty virus-like particles of hepatitis E virus. J. Virol. 71, 7207-7213.

Liang, Y., Yao, J., and Gillam, S. (2000). Rubella virus nonstructural protein protease domains involved in trans- and cis-cleavage activities. J. Virol. 74, 5412-5423. doi: 10.1128/JVI.74.12.5412-5423.2000

Lin, J., Norder, H., Uhlhorn, H., Belak, S., and Widen, F. (2014). Novel hepatitis E like virus found in Swedish moose. J. Gen. Virol. 95, 557-570. doi: 10.1099/vir.0.059238-0

Liu, H., Fu, Y., Jiang, D., Li, G., Xie, J., Peng, Y., et al. (2009). A novel mycovirus that is related to the human pathogen hepatitis $\mathrm{E}$ virus and rubi-like viruses. J. Virol. 83, 1981-1991. doi: 10.1128/JVI.01897-08

Liu, P., Du, R., Wang, L., Han, J., Liu, L., Zhang, Y., et al. (2014). Management of hepatitis E virus (HEV) zoonotic transmission: protection of rabbits against HEV challenge following immunization with HEV 239 vaccine. PLoS ONE 9:e87600. doi: 10.1371/journal.pone.0087600 
Liu, X., Wang, Q., Chen, W., and Wang, C. (2013). Dynamic regulation of innate immunity by ubiquitin and ubiquitin-like proteins. Cytokine Growth Factor Rev. 24, 559-570. doi: 10.1016/j.cytogfr.2013.07.002

Lorenzo, F. R., Tsatsralt-Od, B., Ganbat, S., Takahashi, M., and Okamoto, H. (2007). Analysis of the full-length genome of hepatitis $\mathrm{E}$ virus isolates obtained from farm pigs in Mongolia. J. Med. Virol. 79, 1128-1137. doi: 10.1002/jmv.20905

Lu, L., Li, C., and Hagedorn, C. H. (2006). Phylogenetic analysis of global hepatitis E virus sequences: genetic diversity, subtypes and zoonosis. Rev. Med. Virol. 16, 5-36. doi: 10.1002/rmv.482

Magden, J., Takeda, N., Li, T., Auvinen, P., Ahola, T., Miyamura, T., et al. (2001). Virus-specific mRNA capping enzyme encoded by hepatitis E virus. J. Virol. 75, 6249-6255. doi: 10.1128/JVI.75.14.6249-6255.2001

Majumdar, M., Ratho, R. K., Chawla, Y., and Singh, M. P. (2015). Role of TLR gene expression and cytokine profiling in the immunopathogenesis of viral hepatitis E. J. Clin. Virol. 73, 8-13. doi: 10.1016/j.jcv.2015.09.011

Mallet, V., Nicand, E., Sultanik, P., Chakvetadze, C., Tesse, S., Thervet, E., et al. (2010). Brief communication: case reports of ribavirin treatment for chronic hepatitis E. Ann. Intern. Med. 153, 85-89. doi: 10.7326/0003-4819-153-2201007200-00257

Mao, A. P., Li, S., Zhong, B., Li, Y., Yan, J., Li, Q., et al. (2010). Virus-triggered ubiquitination of TRAF3/ 6 by cIAP1/2 is essential for induction of interferonbeta (IFN-beta) and cellular antiviral response. J. Biol. Chem. 285, 9470-9476. doi: 10.1074/jbc.M109.071043

Marr, L. D., Wang, C. Y., and Frey, T. K. (1994). Expression of the rubella virus nonstructural protein ORF and demonstration of proteolytic processing. Virology 198, 586-592. doi: 10.1006/viro.1994.1070

Martzen, M. R., Mccraith, S. M., Spinelli, S. L., Torres, F. M., Fields, S., Grayhack, E. J., et al. (1999). A biochemical genomics approach for identifying genes by the activity of their products. Science 286, 1153-1155. doi: 10.1126/science.286.5442.1153

Mast, E. E., Alter, M. J., Holland, P. V., and Purcell, R. H. (1998). Evaluation of assays for antibody to hepatitis $\mathrm{E}$ virus by a serum panel. Hepatitis E virus antibody serum panel evaluation group. Hepatology 27, 857-861. doi: 10.1002/hep. 510270331

McAtee, C. P., Zhang, Y., Yarbough, P. O., Bird, T., and Fuerst, T. R. (1996). Purification of a soluble hepatitis E open reading frame 2-derived protein with unique antigenic properties. Protein Expr. Purif. 8, 262-270. doi: 10.1006/prep.1996.0099

Mendell, J. R., Rodino-Klapac, L. R., Sahenk, Z., Roush, K., Bird, L., Lowes, L. P., et al. (2013). Eteplirsen for the treatment of Duchenne muscular dystrophy. Ann. Neurol. 74, 637-647. doi: 10.1002/ana.23982

Meng, J., Dai, X., Chang, J. C., Lopareva, E., Pillot, J., Fields, H. A., et al. (2001). Identification and characterization of the neutralization epitope(s) of the hepatitis E virus. Virology 288, 203-211. doi: 10.1006/viro.2001.1093

Meng, X. J. (2010). Recent advances in Hepatitis E virus. J. Viral. Hepat. 17, 153-161. doi: 10.1111/j.1365-2893.2009.01257.x

Meng, X. J. (2013). Zoonotic and foodborne transmission of hepatitis E virus. Semin. Liver Dis. 33, 41-49. doi: 10.1055/s-0033-1338113

Meng, X. J., Purcell, R. H., Halbur, P. G., Lehman, J. R., Webb, D. M., Tsareva, T. S., et al. (1997). A novel virus in swine is closely related to the human hepatitis $\mathrm{E}$ virus. Proc. Natl. Acad. Sci. U.S.A. 94, 9860-9865. doi: 10.1073/pnas.94.18.9860

Mhaindarkar, V., Sharma, K., and Lole, K. S. (2014). Mutagenesis of hepatitis E virus helicase motifs: effects on enzyme activity. Virus Res. 179, 26-33. doi: 10.1016/j.virusres.2013.11.022

Midgley, S., Vestergaard, H. T., Dalgaard, C., Enggaard, L., and Fischer, T. K. (2014). Hepatitis E virus genotype 4, Denmark, 2012. Emerg. Infect. Dis. 20, 156-157. doi: 10.3201/eid2001.130600

Mizuo, H., Suzuki, K., Takikawa, Y., Sugai, Y., Tokita, H., Akahane, Y., et al. (2002). Polyphyletic strains of hepatitis E virus are responsible for sporadic cases of acute hepatitis in Japan. J. Clin. Microbiol. 40, 3209-3218. doi: 10.1128/JCM.40.9.3209-3218.2002

Moin, S. M., Chandra, V., Arya, R., and Jameel, S. (2009). The hepatitis E virus ORF3 protein stabilizes HIF-1alpha and enhances HIF-1-mediated transcriptional activity through p300/CBP. Cell Microbiol. 11, 1409-1421. doi: 10.1111/j.1462-5822.2009.01340.x

Moin, S. M., Panteva, M., and Jameel, S. (2007). The hepatitis E virus Orf3 protein protects cells from mitochondrial depolarization and death. J. Biol. Chem. 282, 21124-21133. doi: 10.1074/jbc.M701696200
Mori, Y., and Matsuura, Y. (2011). Structure of hepatitis E viral particle. Virus Res. 161, 59-64. doi: 10.1016/j.virusres.2011.03.015

Moulton, H. M. (2013). In vivo delivery of morpholino oligos by cell-penetrating peptides. Curr. Pharm. Des. 19, 2963-2969. doi: 10.2174/13816128113191 60010

Nagashima, S., Takahashi, M., Jirintai, S., Tanggis, Kobayashi, T., Nishizawa, T., and Okamoto, H. (2014). The membrane on the surface of hepatitis E virus particles is derived from the intracellular membrane and contains trans-Golgi network protein 2. Arch. Virol. 159, 979-991. doi: 10.1007/s00705-013-1912-3

Nagashima, S., Takahashi, M., Jirintai, S., Tanaka, T., Nishizawa, T., Yasuda, J., et al. (2011a). Tumour susceptibility gene 101 and the vacuolar protein sorting pathway are required for the release of hepatitis E virions. J. Gen. Virol. 92(Pt. 12), 2838-2848. doi: 10.1099/vir.0.035378-0

Nagashima, S., Takahashi, M., Jirintai, Tanaka, T., Yamada, K., Nishizawa, T., et al. (2011b). A PSAP motif in the ORF3 protein of hepatitis E virus is necessary for virion release from infected cells. J. Gen. Virol. 92, 269-278. doi: 10.1099/vir.0.025791-0

Nair, V. P., Anang, S., Subramani, C., Madhvi, A., Bakshi, K., Srivastava, A., et al. (2016). Endoplasmic reticulum stress induced synthesis of a novel viral factor mediates efficient replication of genotype-1 hepatitis E virus. PLoS Pathog. 12:e1005521. doi: 10.1371/journal.ppat.1005521

Nan, Y. (2014). Interferense of Host Innate Immune Response by Hepatitis E Virus. Ph.D. thesis, University of Maryland, College Park, College Park, MD.

Nan, Y., Ma, Z., Kannan, H., Stein, D. A., Iversen, P. I., Meng, X. J., et al. (2015). Inhibition of hepatitis $\mathrm{E}$ virus replication by peptide-conjugated morpholino oligomers. Antiviral Res. 120, 134-139. doi: 10.1016/j.antiviral.2015.06.006

Nan, Y., Ma, Z., Wang, R., Yu, Y., Kannan, H., Fredericksen, B., et al. (2014a). Enhancement of interferon induction by ORF3 product of hepatitis E virus. J. Virol. 88, 8696-8705. doi: 10.1128/JVI.01228-14

Nan, Y., Yu, Y., Ma, Z., Khattar, S. K., Fredericksen, B., and Zhang, Y. J. (2014b). Hepatitis E virus inhibits type I interferon induction by ORF1 products. J. Virol. 88, 11924-11932. doi: 10.1128/JVI.01935-14

Neuvonen, M., and Ahola, T. (2009). Differential activities of cellular and viral macro domain proteins in binding of ADP-ribose metabolites. J. Mol. Biol. 385, 212-225. doi: 10.1016/j.jmb.2008.10.045

Ojha, N. K., and Lole, K. S. (2016). Hepatitis E virus ORF1 encoded macro domain protein interacts with light chain subunit of human ferritin and inhibits its secretion. Mol. Cell. Biochem. 417, 75-85. doi: 10.1007/s11010-016-2 715-0

Okamoto, H. (2007). Genetic variability and evolution of hepatitis E virus. Virus Res. 127, 216-228. doi: 10.1016/j.virusres.2007.02.002

Okamoto, H. (2011). Efficient cell culture systems for hepatitis E virus strains in feces and circulating blood. Rev. Med. Virol. 21, 18-31. doi: 10.1002/rmv.678

Okamoto, H. (2013). Culture systems for hepatitis E virus. J. Gastroenterol. 48, 147-158. doi: 10.1007/s00535-012-0682-0

O'Reilly, E. K., and Kao, C. C. (1998). Analysis of RNA-dependent RNA polymerase structure and function as guided by known polymerase structures and computer predictions of secondary structure. Virology 252, 287-303. doi: 10.1006/viro.1998.9463

Osterman, A., Stellberger, T., Gebhardt, A., Kurz, M., Friedel, C. C., Uetz, P., et al. (2015). The hepatitis E virus intraviral interactome. Sci. Rep. 5, 13872. doi: $10.1038 /$ srep 13872

Paessler, S., Rijnbrand, R., Stein, D. A., Ni, H., Yun, N. E., Dziuba, N., et al. (2008). Inhibition of alphavirus infection in cell culture and in mice with antisense morpholino oligomers. Virology 376, 357-370. doi: 10.1016/j.virol.2008.03.032

Paliwal, D., Panda, S. K., Kapur, N., Varma, S. P., and Durgapal, H. (2014). Hepatitis E virus (HEV) protease: a chymotrypsin-like enzyme that processes both non-structural (pORF1) and capsid (pORF2) protein. J. Gen. Virol. 95(Pt. 8), 1689-700. doi: 10.1099/vir.0.066142-0

Panda, S. K., Ansari, I. H., Durgapal, H., Agrawal, S., and Jameel, S. (2000). The in vitro-synthesized RNA from a cDNA clone of hepatitis E virus is infectious. J. Virol. 74, 2430-2437. doi: 10.1128/JVI.74.5.2430-2437.2000

Parvez, M. K. (2013). Molecular characterization of hepatitis E virus ORF1 gene supports a papain-like cysteine protease (PCP)-domain activity. Virus Res. 178, 553-556. doi: 10.1016/j.virusres.2013.07.020

Parvez, M. K. (2015a). The hepatitis E virus ORF1 'X-domain' residues form a putative macrodomain protein/Appr-1-pase catalytic-site, critical for viral RNA replication. Gene 566, 47-53. doi: 10.1016/j.gene.2015.04.026 
Parvez, M. K. (2015b). The intergenic-junction variant (genotype 2 isolate) of hepatitis E virus restores the CREX 'stem-loop' structural integrity, essential for viral life cycle. Gene 559, 149-154. doi: 10.1016/j.gene.2015.01.033

Parvez, M. K., and Al-Dosari, M. S. (2015). Evidence of MAPK-JNK1/2 activation by hepatitis E virus ORF3 protein in cultured hepatoma cells. Cytotechnology 67, 545-550. doi: 10.1007/s10616-014-9785-1

Pas, S. D., De Man, R. A., Mulders, C., Balk, A. H., Van Hal, P. T., Weimar, W., et al. (2012). Hepatitis E virus infection among solid organ transplant recipients, the Netherlands. Emerg. Infect. Dis. 18, 869-872. doi: 10.3201/eid1805.111712

Pasdeloup, D., Mcelwee, M., Beilstein, F., Labetoulle, M., and Rixon, F. J. (2013). Herpesvirus tegument protein pUL37 interacts with dystonin/BPAG1 to promote capsid transport on microtubules during egress. J. Virol. 87, 28572867. doi: 10.1128/JVI.02676-12

Pavio, N., Meng, X. J., and Doceul, V. (2015). Zoonotic origin of hepatitis E. Curr. Opin. Virol. 10, 34-41. doi: 10.1016/j.coviro.2014.12.006

Pehrson, J. R., and Fried, V. A. (1992). MacroH2A, a core histone containing a large nonhistone region. Science 257, 1398-1400. doi: 10.1126/science.1529340

Pehrson, J. R., and Fuji, R. N. (1998). Evolutionary conservation of histone macroH2A subtypes and domains. Nucleic Acids Res. 26, 2837-2842. doi: 10.1093/nar/26.12.2837

Perche, P. Y., Vourc'h, C., Konecny, L., Souchier, C., Robert-Nicoud, M., Dimitrov, S., et al. (2000). Higher concentrations of histone macroH2A in the Barr body are correlated with higher nucleosome density. Curr. Biol. 10, 1531-1534. doi: 10.1016/S0960-9822(00)00832-0

Perttila, J., Spuul, P., and Ahola, T. (2013). Early secretory pathway localization and lack of processing for hepatitis E virus replication protein pORF1. J. Gen. Virol. 94, 807-816. doi: 10.1099/vir.0.049577-0

Pudupakam, R. S., Huang, Y. W., Opriessnig, T., Halbur, P. G., Pierson, F. W., and Meng, X. J. (2009). Deletions of the hypervariable region (HVR) in open reading frame 1 of hepatitis $\mathrm{E}$ virus do not abolish virus infectivity: evidence for attenuation of HVR deletion mutants in vivo. J. Virol. 83, 384-395. doi: 10.1128/JVI.01854-08

Pudupakam, R. S., Kenney, S. P., Cordoba, L., Huang, Y. W., Dryman, B. A., Leroith, T., et al. (2011). Mutational analysis of the hypervariable region of hepatitis e virus reveals its involvement in the efficiency of viral RNA replication. J. Virol. 85, 10031-10040. doi: 10.1128/JVI.00763-11

Purcell, R. H., and Emerson, S. U. (2008). Hepatitis E: an emerging awareness of an old disease. J. Hepatol. 48, 494-503. doi: 10.1016/j.jhep.2007.12.008

Purdy, M. A. (2012). Evolution of the hepatitis E virus polyproline region: order from disorder. J. Virol. 86, 10186-10193. doi: 10.1128/JVI.01374-12

Purdy, M. A., and Khudyakov, Y. E. (2011). The molecular epidemiology of hepatitis E virus infection. Virus Res. 161, 31-39. doi: 10.1016/j.virusres. 2011.04.030

Purdy, M. A., Lara, J., and Khudyakov, Y. E. (2012). The hepatitis E virus polyproline region is involved in viral adaptation. PLOS ONE 7, e35974. doi: 10.1371/journal.pone.0035974

Putics, A., Filipowicz, W., Hall, J., Gorbalenya, A. E., and Ziebuhr, J. (2005). ADP-ribose-1"-monophosphatase: a conserved coronavirus enzyme that is dispensable for viral replication in tissue culture. J. Virol. 79, 12721-12731. doi: 10.1128/JVI.79.20.12721-12731.2005

Putics, A., Gorbalenya, A. E., and Ziebuhr, J. (2006). Identification of protease and ADP-ribose 1"-monophosphatase activities associated with transmissible gastroenteritis virus non-structural protein 3. J. Gen. Virol. 87, 651-656. doi: 10.1099/vir.0.81596-0

Qi, Y., Zhang, F., Zhang, L., Harrison, T. J., Huang, W., Zhao, C., et al. (2015). Hepatitis E virus produced from cell culture has a lipid envelope. PLoS ONE 10:e0132503. doi: 10.1371/journal.pone.0132503

Raeder, R., Woischnik, M., Podbielski, A., and Boyle, M. D. (1998). A secreted streptococcal cysteine protease can cleave a surface-expressed M1 protein and alter the immunoglobulin binding properties. Res. Microbiol. 149, 539-548. doi: 10.1016/S0923-2508(99)80001-1

Raj, V. S., Smits, S. L., Pas, S. D., Provacia, L. B., Moorman-Roest, H., Osterhaus, A. D., et al. (2012). Novel hepatitis E virus in ferrets, the Netherlands. Emerg. Infect. Dis. 18, 1369-1370. doi: 10.3201/eid1808.111659

Ratra, R., Kar-Roy, A., and Lal, S. K. (2008). The ORF3 protein of hepatitis E virus interacts with hemopexin by means of its 26 amino acid $\mathrm{N}$-terminal hydrophobic domain II. Biochemistry 47, 1957-1969. doi: 10.1021/bi70 16552
Ratra, R., Kar-Roy, A., and Lal, S. K. (2009). ORF3 protein of hepatitis E virus interacts with the Bbeta chain of fibrinogen resulting in decreased fibrinogen secretion from HuH-7 cells. J. Gen. Virol. 90, 1359-1370. doi: 10.1099/vir.0.009274-0

Rehman, S., Kapur, N., Durgapal, H., and Panda, S. K. (2008). Subcellular localization of hepatitis E virus (HEV) replicase. Virology 370, 77-92. doi: 10.1016/j.virol.2007.07.036

Reyes, G. R., Huang, C. C., Tam, A. W., and Purdy, M. A. (1993). Molecular organization and replication of hepatitis E virus (HEV). Arch. Virol. Suppl. 7, 15-25. doi: 10.1007/978-3-7091-9300-6_2

Reyes, G. R., Purdy, M. A., Kim, J. P., Luk, K. C., Young, L. M., Fry, K. E., et al. (1990). Isolation of a cDNA from the virus responsible for enterically transmitted non-A, non-B hepatitis. Science 247, 1335-1339. doi: $10.1126 /$ science. 2107574

Robinson, R. A., Burgess, W. H., Emerson, S. U., Leibowitz, R. S., Sosnovtseva, S. A., Tsarev, S., et al. (1998). Structural characterization of recombinant hepatitis E virus ORF2 proteins in baculovirus-infected insect cells. Protein Expr. Purif. 12, 75-84. doi: 10.1006/prep.1997.0817

Rogee, S., Talbot, N., Caperna, T., Bouquet, J., Barnaud, E., and Pavio, N. (2013). New models of hepatitis $\mathrm{E}$ virus replication in human and porcine hepatocyte cell lines. J. Gen. Virol. 94, 549-558. doi: 10.1099/vir.0.049858-0

Ropp, S. L., Tam, A. W., Beames, B., Purdy, M., and Frey, T. K. (2000). Expression of the hepatitis E virus ORF1. Arch. Virol. 145, 1321-1337. doi: $10.1007 / \mathrm{s} 007050070093$

Rozanov, M. N., Koonin, E. V., and Gorbalenya, A. E. (1992). Conservation of the putative methyltransferase domain: a hallmark of the 'Sindbis-like' supergroup of positive-strand RNA viruses. J. Gen. Virol. 73 (Pt 8), 2129-2134. doi: 10.1099/0022-1317-73-8-2129

Sadler, G. J., Mells, G. F., Shah, N. H., Chesner, I. M., and Walt, R. P. (2006). UK acquired hepatitis E-An emerging problem? J. Med. Virol. 78, 473-475. doi: 10.1002/jmv.20564

Saikatendu, K. S., Joseph, J. S., Subramanian, V., Clayton, T., Griffith, M., Moy, K., et al. (2005). Structural basis of severe acute respiratory syndrome coronavirus ADP-ribose-1"-phosphate dephosphorylation by a conserved domain of nsP3. Structure 13, 1665-1675. doi: 10.1016/j.str.2005.07.022

Sanford, B. J., Opriessnig, T., Kenney, S. P., Dryman, B. A., Cordoba, L., and Meng, X. J. (2012). Assessment of the cross-protective capability of recombinant capsid proteins derived from pig, rat, and avian hepatitis E viruses (HEV) against challenge with a genotype $3 \mathrm{HEV}$ in pigs. Vaccine $30,6249-6255$. doi: 10.1016/j.vaccine.2012.08.013

Sayed, I. M., Vercouter, A. S., Abdelwahab, S. F., Vercauteren, K., and Meuleman, P. (2015). Is hepatitis E virus an emerging problem in industrialized countries? Hepatology 62, 1883-1892. doi: 10.1002/hep.27990

Schlauder, G. G., Desai, S. M., Zanetti, A. R., Tassopoulos, N. C., and Mushahwar, I. K. (1999). Novel hepatitis E virus (HEV) isolates from Europe: evidence for additional genotypes of HEV. J. Med. Virol. 57, 243-251. doi: 10.1002/(SICI)1096-9071(199903)57:3<243::AID-JMV6>3.0.CO;2-R

Schofield, D. J., Glamann, J., Emerson, S. U., and Purcell, R. H. (2000). Identification by phage display and characterization of two neutralizing chimpanzee monoclonal antibodies to the hepatitis E virus capsid protein. J. Virol. 74, 5548-5555. doi: 10.1128/JVI.74.12.5548-5555.2000

Sehgal, D., Thomas, S., Chakraborty, M., and Jameel, S. (2006). Expression and processing of the Hepatitis E virus ORF1 nonstructural polyprotein. Virol. J. 3, 38. doi: 10.1186/1743-422X-3-38

Semiletov, Y. A., Dementeva, E. V., Yashina, T. L., Favorov, M. O., and Shibnev, V. A. (1995). Synthesis and antigenic activity of peptides from the Orf3 protein-sequence of hepatitis-E virus. Bioorg. Khim. 21, 156-157.

Shrestha, M. P., Scott, R. M., Joshi, D. M., Mammen, M. P. Jr., Thapa, G. B., Thapa, N., et al. (2007). Safety and efficacy of a recombinant hepatitis E vaccine. N. Engl. J. Med. 356, 895-903. doi: 10.1056/NEJMoa061847

Shukla, P., Nguyen, H. T., Torian, U., Engle, R. E., Faulk, K., Dalton, H. R., et al. (2011). Cross-species infections of cultured cells by hepatitis E virus and discovery of an infectious virus-host recombinant. Proc. Natl. Acad. Sci. U.S.A. 108, 2438-2443. doi: 10.1073/pnas.1018878108

Singleton, M. R., Dillingham, M. S., and Wigley, D. B. (2007). Structure and mechanism of helicases and nucleic acid translocases. Annu. Rev. Biochem. 76, 23-50. doi: 10.1146/annurev.biochem.76.052305.115300 
Smith, D. B., Purdy, M. A., and Simmonds, P. (2013). Genetic variability and the classification of hepatitis E virus. J. Virol. 87, 4161-4169. doi: 10.1128/JVI.02762-12

Smith, D. B., Simmonds, P., Izopet, J., Oliveira-Filho, E. F., Ulrich, R. G., Johne, R., et al. (2016). Proposed reference sequences for hepatitis E virus subtypes. J. Gen. Virol. 97, 537-542. doi: 10.1099/jgv.0.000393

Smith, D. B., Simmonds, P., Jameel, S., Emerson, S. U., Harrison, T. J., Meng, X. J., et al. (2014). Consensus proposals for classification of the family Hepeviridae. J. Gen. Virol. 95, 2223-2232. doi: 10.1099/vir.0.068429-0

Sue, P. K., Pisanic, N., Heaney, C. D., Forman, M., Valsamakis, A., Jackson, A. M., et al. (2016). Hepatitis $\mathrm{E}$ virus infection among solid organ transplant recipients at a North American transplant center. Open Forum Infect. Dis. 3:ofw006. doi: 10.1093/ofid/ofw006

Summerton, J. (1999). Morpholino antisense oligomers: the case for an RNase H-independent structural type. Biochim. Biophys. Acta 1489, 141-158. doi: 10.1016/S0167-4781(99)00150-5

Sun, Z., Chen, Z., Lawson, S. R., and Fang, Y. (2010). The cysteine protease domain of porcine reproductive and respiratory syndrome virus nonstructural protein 2 possesses deubiquitinating and interferon antagonism functions. J. Virol. 84, 7832-7846. doi: 10.1128/JVI.00217-10

Suppiah, S., Zhou, Y., and Frey, T. K. (2011). Lack of processing of the expressed ORF1 gene product of hepatitis E virus. Virol. J. 8, 245. doi: 10.1186/1743-422X$8-245$

Surjit, M., Jameel, S., and Lal, S. K. (2004). The ORF2 protein of hepatitis E virus binds the $5^{\prime}$ region of viral RNA. J. Virol. 78, 320-328. doi: 10.1128/JVI.78.1.320328.2004

Surjit, M., Varshney, B., and Lal, S. K. (2012). The ORF2 glycoprotein of hepatitis E virus inhibits cellular NF-kappaB activity by blocking ubiquitination mediated proteasomal degradation of IkappaBalpha in human hepatoma cells. BMC Biochem. 13:7. doi: 10.1186/1471-2091-13-7

Takahashi, H., Tanaka, T., Jirintai, S., Nagashima, S., Takahashi, M., Nishizawa, T., et al. (2012). A549 and PLC/PRF/5 cells can support the efficient propagation of swine and wild boar hepatitis E virus (HEV) strains: demonstration of HEV infectivity of porcine liver sold as food. Arch. Virol. 157, 235-246. doi: 10.1007/s00705-011-1153-2

Takahashi, K., Kitajima, N., Abe, N., and Mishiro, S. (2004). Complete or nearcomplete nucleotide sequences of hepatitis $\mathrm{E}$ virus genome recovered from a wild boar, a deer, and four patients who ate the deer. Virology 330, 501-505. doi: 10.1016/j.virol.2004.10.006

Takahashi, M., Nishizawa, T., Sato, H., Sato, Y., Jirintai, Nagashima, S., et al. (2011). Analysis of the full-length genome of a hepatitis E virus isolate obtained from a wild boar in Japan that is classifiable into a novel genotype. J. Gen. Virol. 92, 902-908. doi: 10.1099/vir.0.029470-0

Takahashi, M., Tanaka, T., Takahashi, H., Hoshino, Y., Nagashima, S., Jirintai, et al. (2010). Hepatitis E Virus (HEV) strains in serum samples can replicate efficiently in cultured cells despite the coexistence of HEV antibodies: characterization of HEV virions in blood circulation. J. Clin. Microbiol. 48, 1112-1125. doi: 10.1128/JCM.02002-09

Takahashi, M., Yamada, K., Hoshino, Y., Takahashi, H., Ichiyama, K., Tanaka, T., et al. (2008). Monoclonal antibodies raised against the ORF3 protein of hepatitis E virus (HEV) can capture HEV particles in culture supernatant and serum but not those in feces. Arch. Virol. 153, 1703-1713. doi: 10.1007/s00705-008$0179-6$

Tam, A. W., Smith, M. M., Guerra, M. E., Huang, C. C., Bradley, D. W., Fry, K. E., et al. (1991). Hepatitis E virus (HEV): molecular cloning and sequencing of the full-length viral genome. Virology 185, 120-131. doi: 10.1016/00426822(91)90760-9

Tam, A.W., White, R., Reed, E., Short, M., Zhang, Y., Fuerst, T.R., et al. (1996). In vitro propagation and production of hepatitis $\mathrm{E}$ virus from in vivo-infected primary macaque hepatocytes. Virology 215, 1-9. doi: 10.1006/viro.1996.0001

Tanaka, T., Takahashi, M., Kusano, E., and Okamoto, H. (2007). Development and evaluation of an efficient cell-culture system for hepatitis E virus. J. Gen. Virol. 88, 903-911. doi: 10.1099/vir.0.82535-0

Tanaka, T., Takahashi, M., Takahashi, H., Ichiyama, K., Hoshino, Y., Nagashima, S., et al. (2009). Development and characterization of a genotype 4 hepatitis E virus cell culture system using a HE-JF5/15F strain recovered from a fulminant hepatitis patient. J. Clin. Microbiol. 47, 1906-1910. doi: 10.1128/JCM. 00629-09
Tang, Z. M., Tang, M., Zhao, M., Wen, G. P., Yang, F., Cai, W., et al. (2015). A novel linear neutralizing epitope of hepatitis E virus. Vaccine 33, 3504-3511. doi: $10.1016 /$ j.vaccine.2015.05.065

Tei, S., Kitajima, N., Takahashi, K., and Mishiro, S. (2003). Zoonotic transmission of hepatitis E virus from deer to human beings. Lancet 362, 371-373. doi: 10.1016/S0140-6736(03)14025-1

Todt, D., Gisa, A., Radonic, A., Nitsche, A., Behrendt, P., Suneetha, P.V., et al. (2016). In vivo evidence for ribavirin-induced mutagenesis of the hepatitis E virus genome. Gut doi: 10.1136/gutjnl-2015-311000. [Epub ahead of print]

Tsai, C. J., Ma, B., Sham, Y. Y., Kumar, S., and Nussinov, R. (2001). Structured disorder and conformational selection. Proteins 44, 418-427. doi: $10.1002 /$ prot. 1107

Tsarev, S. A., Emerson, S. U., Reyes, G. R., Tsareva, T. S., Legters, L. J., Malik, I. A., et al. (1992). Characterization of a prototype strain of hepatitis E virus. Proc. Natl. Acad. Sci. U.S.A. 89, 559-563. doi: 10.1073/pnas.89. 2.559

Tsarev, S. A., Tsareva, T. S., Emerson, S. U., Kapikian, A. Z., Ticehurst, J., London, W., et al. (1993). ELISA for antibody to hepatitis E virus (HEV) based on complete open-reading frame-2 protein expressed in insect cells: identification of HEV infection in primates. J. Infect. Dis. 168, 369-378. doi: 10.1093/infdis/168.2.369

Tyagi, S., Jameel, S., and Lal, S. K. (2001a). The full-length and N-terminal deletion of ORF2 protein of hepatitis E virus can dimerize. Biochem. Biophys. Res. Commun. 286, 214-221. doi: 10.1006/bbrc.2001.5256

Tyagi, S., Jameel, S., and Lal, S. K. (2001b). Self-association and mapping of the interaction domain of hepatitis E virus ORF3 protein. J. Virol. 75, 2493-2498. doi: 10.1128/JVI.75.5.2493-2498.2001

Tyagi, S., Korkaya, H., Zafrullah, M., Jameel, S., and Lal, S. K. (2002). The phosphorylated form of the ORF3 protein of hepatitis E virus interacts with its non-glycosylated form of the major capsid protein, ORF2. J. Biol. Chem. 277, 22759-22767. doi: 10.1074/jbc.M200185200

Tyagi, S., Surjit, M., and Lal, S. K. (2005). The 41-amino-acid C-terminal region of the hepatitis E virus ORF3 protein interacts with bikunin, a kunitz-type serine protease inhibitor. J. Virol. 79, 12081-12087. doi: 10.1128/JVI.79.18.1208112087.2005

Tyagi, S., Surjit, M., Roy, A. K., Jameel, S., and Lal, S. K. (2004). The ORF3 protein of hepatitis $\mathrm{E}$ virus interacts with liver-specific alphal-microglobulin and its precursor alpha1-microglobulin/bikunin precursor (AMBP) and expedites their export from the hepatocyte. J. Biol. Chem. 279, 29308-29319. doi: 10.1074/jbc.M402017200

Tzeng, W. P., Chen, M. H., Derdeyn, C. A., and Frey, T. K. (2001). Rubella virus DI RNAs and replicons: requirement for nonstructural proteins acting in cis for amplification by helper virus. Virology 289, 63-73. doi: 10.1006/viro.2001.1088

van den Berg, B., Van Der Eijk, A. A., Pas, S. D., Hunter, J. G., Madden, R. G., Tio-Gillen, A. P., et al. (2014). Guillain-Barre syndrome associated with preceding hepatitis E virus infection. Neurology 82, 491-497. doi: 10.1212/WNL.0000000000000111

van der Poel, W. H., Verschoor, F., Van Der Heide, R., Herrera, M. I., Vivo, A., Kooreman, M., et al. (2001). Hepatitis E virus sequences in swine related to sequences in humans, The Netherlands. Emerg. Infect. Dis. 7, 970-976. doi: 10.3201/eid0706.010608

van Eijk, J. J., Madden, R. G., Van Der Eijk, A. A., Hunter, J. G., Reimerink, J. H., Bendall, R. P., et al. (2014). Neuralgic amyotrophy and hepatitis E virus infection. Neurology 82, 498-503. doi: 10.1212/WNL.000000000000 0112

van Kasteren, P. B., Bailey-Elkin, B. A., James, T. W., Ninaber, D. K., Beugeling, C., Khajehpour, M., et al. (2013). Deubiquitinase function of arterivirus papainlike protease 2 suppresses the innate immune response in infected host cells. Proc. Natl. Acad. Sci. U.S.A. 110, E838-847. doi: 10.1073/pnas.12184 64110

Wang, H., Ji, F., Liang, H., Gu, H., Ning, Z., Liu, R., et al. (2015). A prolinerich domain in the genotype 4 hepatitis $\mathrm{E}$ virus ORF3 C-terminus is crucial for downstream V105DLP108 immunoactivity. PLoS ONE 10, e0133282. doi: 10.1371/journal.pone.0133282

Wang, L., Cao, D., Wei, C., Meng, X. J., Jiang, X., and Tan, M. (2014a). A dual vaccine candidate against norovirus and hepatitis $\mathrm{E}$ virus. Vaccine 32, 445-452. doi: $10.1016 /$ j.vaccine.2013.11.064 
Wang, L., Sun, Y., Du, T., Wang, C., Xiao, S., Mu, Y., et al. (2014b). Identification of an antigenic domain in the $\mathrm{N}$-terminal region of avian hepatitis $\mathrm{E}$ virus (HEV) capsid protein that is not common to swine and human HEVs. J. Gen. Virol. 95, 2710-2715. doi: 10.1099/vir.0.069021-0

Ward, P., Leblanc, D., Houde, A., and Brassard, J. (2015). Analysis of complete genome sequences and a V239A substitution in the helicase domain of swine hepatitis E virus strains isolated in Canada. Arch. Virol. 160, 1767-1773. doi: 10.1007/s00705-015-2429-8

Wedemeyer, H., Pischke, S., and Manns, M. P. (2012). Pathogenesis and treatment of hepatitis e virus infection. Gastroenterology 142, 1388-1397 el. doi: 10.1053/j.gastro.2012.02.014

Wei, S., Walsh, P., Huang, R., and To, S. S. (2000). 93G, a novel sporadic strain of hepatitis E virus in South China isolated by cell culture. J. Med. Virol. 61, 311-318. doi: 10.1002/1096-9071(200007)61:3<311::AID-JMV5>3.0.CO;2-H

WHO (2015). Hepatitis E [Online]. Available at: http://www.who.int/mediacentre/ factsheets/fs280/en/

Woo, P. C., Lau, S. K., Teng, J. L., Tsang, A. K., Joseph, M., Wong, E. Y., et al. (2014). New hepatitis E virus genotype in camels, the Middle East. Emerg. Infect. Dis. 20, 1044-1048. doi: 10.3201/eid2006.140140

Worm, H. C., Schlauder, G. G., Wurzer, H., and Mushahwar, I. K. (2000). Identification of a novel variant of hepatitis $\mathrm{E}$ virus in Austria: sequence, phylogenetic and serological analysis. J. Gen. Virol. 81, 2885-2890. doi: 10.1099/0022-1317-81-12-2885

Xia, M., Wei, C., Wang, L., Cao, D., Meng, X. J., Jiang, X., et al. (2016). Development and evaluation of two subunit vaccine candidates containing antigens of hepatitis E virus, rotavirus, and astrovirus. Sci. Rep. 6, 25735. doi: $10.1038 /$ srep 25735

Xiaofang, L., Zafrullah, M., Ahmad, F., and Jameel, S. (2001). A C-terminal hydrophobic region is required for homo-oligomerization of the hepatitis E virus capsid (ORF2) protein. J. Biomed. Biotechnol. 1, 122-128. doi: $10.1155 /$ S1110724301000262

Xing, L., Wang, J. C., Li, T. C., Yasutomi, Y., Lara, J., Khudyakov, Y., et al. (2011). Spatial configuration of hepatitis E virus antigenic domain. J. Virol. 85, 1117-1124. doi: 10.1128/JVI.00657-10

Yamada, K., Takahashi, M., Hoshino, Y., Takahashi, H., Ichiyama, K., Nagashima, S., et al. (2009). ORF3 protein of hepatitis E virus is essential for virion release from infected cells. J. Gen. Virol. 90, 1880-1891. doi: 10.1099/vir.0.010561-0

Yamashita, T., Mori, Y., Miyazaki, N., Cheng, R. H., Yoshimura, M., Unno, H., et al. (2009). Biological and immunological characteristics of hepatitis E viruslike particles based on the crystal structure. Proc. Natl. Acad. Sci. U.S.A. 106, 12986-12991. doi: 10.1073/pnas.0903699106

Yazaki, Y., Mizuo, H., Takahashi, M., Nishizawa, T., Sasaki, N., Gotanda, Y., et al. (2003). Sporadic acute or fulminant hepatitis E in Hokkaido, Japan, may be food-borne, as suggested by the presence of hepatitis E virus in pig liver as food. J. Gen. Virol. 84, 2351-2357. doi: 10.1099/vir.0.19242-0

Yin, X., Ambardekar, C., Lu, Y., and Feng, Z. (2016). Distinct entry mechanisms for nonenveloped and quasi-enveloped hepatitis E viruses. J. Virol. 90, 4232-4242. doi: 10.1128/JVI.02804-15

Yu, H., Li, S., Yang, C., Wei, M., Song, C., Zheng, Z., et al. (2011). Homology model and potential virus-capsid binding site of a putative HEV receptor Grp78. J. Mol. Model. 17, 987-995. doi: 10.1007/s00894-010-0794-5
Zafrullah, M., Ozdener, M. H., Kumar, R., Panda, S. K., and Jameel, S. (1999). Mutational analysis of glycosylation, membrane translocation, and cell surface expression of the hepatitis E virus ORF2 protein. J. Virol. 73, 4074-4082.

Zafrullah, M., Ozdener, M. H., Panda, S. K., and Jameel, S. (1997). The ORF3 protein of hepatitis $\mathrm{E}$ virus is a phosphoprotein that associates with the cytoskeleton. J. Virol. 71, 9045-9053.

Zarrinpar, A., Bhattacharyya, R. P., and Lim, W. A. (2003). The structure and function of proline recognition domains. Sci. STKE 2003: RE8. doi: 10.1126/stke.2003.179.re8

Zeng, W., Xu, M., Liu, S., Sun, L., and Chen, Z. J. (2009). Key role of Ubc5 and lysine-63 polyubiquitination in viral activation of IRF3. Mol. Cell 36, 315-325. doi: 10.1016/j.molcel.2009.09.037

Zhang, M., Purcell, R. H., and Emerson, S. U. (2001). Identification of the $5^{\prime}$ terminal sequence of the SAR-55 and MEX-14 strains of hepatitis E virus and confirmation that the genome is capped. J. Med. Virol. 65, 293-295. doi: 10.1002/jmv.2032

Zhang, W., Hua, X., Shen, Q., Yang, S., Yin, H., and Cui, L. (2011). Identification of genotype 4 hepatitis E virus binding proteins on swine liver cells. Virol. J. 8, 482. doi: 10.1186/1743-422X-8-482

Zhang, Y., Mcatee, P., Yarbough, P. O., Tam, A. W., and Fuerst, T. (1997). Expression, characterization, and immunoreactivities of a soluble hepatitis E virus putative capsid protein species expressed in insect cells. Clin. Diagn. Lab. Immunol. 4, 423-428.

Zhang, Y., Zeng, H., Liu, P., Liu, L., Xia, J., Wang, L., et al. (2015). Hepatitis E vaccine immunization for rabbits to prevent animal HEV infection and zoonotic transmission. Vaccine 33, 4922-4928. doi: 10.1016/j.vaccine.2015.07.040

Zhao, C., Ma, Z., Harrison, T. J., Feng, R., Zhang, C., Qiao, Z., et al. (2009). A novel genotype of hepatitis E virus prevalent among farmed rabbits in China. J. Med. Virol. 81, 1371-1379. doi: 10.1002/jmv.21536

Zheng, Z. Z., Miao, J., Zhao, M., Tang, M., Yeo, A. E., Yu, H., et al. (2010). Role of heat-shock protein 90 in hepatitis E virus capsid trafficking. J. Gen. Virol. 91, 1728-1736. doi: 10.1099/vir.0.019323-0

Zhou, Y. H., Purcell, R. H., and Emerson, S. U. (2004). An ELISA for putative neutralizing antibodies to hepatitis $\mathrm{E}$ virus detects antibodies to genotypes 1, 2, 3, and 4. Vaccine 22, 2578-2585. doi: 10.1016/j.vaccine.2003. 12.017

Zhu, F. C., Zhang, J., Zhang, X. F., Zhou, C., Wang, Z. Z., Huang, S. J., et al. (2010). Efficacy and safety of a recombinant hepatitis $E$ vaccine in healthy adults: a large-scale, randomised, double-blind placebo-controlled, phase 3 trial. Lancet 376, 895-902. doi: 10.1016/S0140-6736(10)61030-6

Conflict of Interest Statement: The authors declare that the research was conducted in the absence of any commercial or financial relationships that could be construed as a potential conflict of interest.

Copyright (c) 2016 Nan and Zhang. This is an open-access article distributed under the terms of the Creative Commons Attribution License (CC BY). The use, distribution or reproduction in other forums is permitted, provided the original author(s) or licensor are credited and that the original publication in this journal is cited, in accordance with accepted academic practice. No use, distribution or reproduction is permitted which does not comply with these terms. 